Acta Protozool. (2018) 57: 169-193

www.ejournals.eu/Acta-Protozoologica

doi:10.4467/16890027AP.18.014.10090

PROTOZOOLOGICA

\title{
Some Ultrastructural Features of the Planktonic Freshwater Ciliate Limnostrombidium viride (Alveolata, Ciliophora, Oligotrichida) and Improved Diagnoses of Oligotrich Taxa
}

\author{
Christian F. BARDELE ${ }^{1}$, Nicole STOCKMANN ${ }^{1}$, Sabine AGATHA ${ }^{2}$ \\ ${ }^{1}$ Department of Evolution and Ecology, University of Tübingen, Tübingen, Germany \\ ${ }^{2}$ Department of Biosciences, University of Salzburg, Salzburg, Austria
}

\begin{abstract}
The first transmission and scanning electron microscopical studies in combination with freeze-fracture technology have disclosed some important morphological and ultrastructural features in the freshwater oligotrichid Limnostrombidium viride. (I) The dikinetids (paired basal bodies) of the girdle kinety have a club-shaped cilium associated only with each left basal body. The electron-dense (paraflagellar) body on one side of its " $9 \times 2+2$ "-axoneme and the regular array of intramembranous particles indicate a sensory, perhaps photoreceptor function of these club-shaped cilia. (II) The stichomonad endoral membrane is proximally covered by a cytoplasmic fold and distally by multiple membranous layers. Thus entirely covered, the endoral is probably no longer involved in food capture; nonetheless, its associated microtubules might stabilise the cytopharynx. (III) Instead of a contractile vacuole, a horizontal ring-canal with supposed osmoregulatory function occurs. (IV) The extrusive nature of the trichites is not only observed in electron micrographs, but the attachment sites of these organelles also display a rosette of " $8+1$ "-particles in the P-face of freeze-fracture replicas typical for ciliate extrusomes. (V) The neoformation organelle, the subsurface tube in which stomatogenesis takes place, shows short basal bodies and normal axonemes about $1 \mu \mathrm{m}$ long. It is accompanied by numerous membrane vesicles, which might provide membrane material for the outgrowing cilia.
\end{abstract}

Keywords: extrusome attachment sites, neoformation organelle, non-motile endoral, ring-canal, sensory cilia

\section{INTRODUCTION}

The planktonic ciliate community in freshwater ponds and lakes is named the Oligotrichetea owing to the high abundances of ciliates belonging to the spirotrich Oligotrichea (Foissner et al. 1995). This taxon is characterised by a hypoapokinetal stomatogenesis and

Address of correspondence: Sabine Agatha, Department of Biosciences, University of Salzburg, A-5020 Salzburg, Austria; E-mail: Sabine.Agatha@sbg.ac.at; Tel.: +43 6628044 5540; Fax. +43 662 80445698 an enantiotropic division mode (Foissner 1996) and embraces two orders, the Oligotrichida and the Choreotrichida; both are monophyletic in cladistic and genetic analyses (Strüder-Kypke and Lynn 2003; Agatha and Strüder-Kypke 2007, 2014; Santoferrara et al. 2017). The oligotrichids comprise four families: the marine Tontoniidae Agatha, 2004 (characterised by a contractile tail); the marine Cyrtostrombidiidae Agatha, 2004 (with strong, cyrtos-like pharyngeal fibres; without buccal membranelles); the freshwater Pelagostrombidiidae Agatha, 2004 (with a neoformation organelle); and the non-monophyletic, mainly marine Strombidiidae Fau- 
ré-Fremiet, 1970 (characterised by only plesiomorphic character states). The Pelagostrombidiidae include two genera, viz., the type genus Pelagostrombidium Krainer, 1991 and Limnostrombidium Krainer, 1995 differing in the shapes of the neoformation organelle (with widened proximal portion vs. entirely tube-shaped) and the adoral zone of membranelles (buccal zone portion longitudinally vs. obliquely orientated, terminating in the posterior vs. anterior cell half) as well as in the number of somatic ciliary rows (girdle kinety vs. girdle and ventral kineties) and the presence of somatic cilia (absent vs. present).

Only few oligotrichids have been studied by means of transmission electron microscopy: Pelagostrombidium mirabile [reported as Strombidium viride by Rogerson et al. (1989)], Strombidium capitatum (Stoecker et al. 1989, Stoecker and Silver 1990), S. acutum, S. chlorophilum, S. conicum (Stoecker et al. 1989), S. inclinatum (Modeo et al. 2001, 2003), S. sulcatum (FauréFremiet and Ganier 1970), Novistrombidium testaceum (Modeo et al. 2003), and tontoniids (Greuet et al. 1986, Laval-Peuto and Febvre 1986, Laval-Peuto et al. 1986). Most of these papers focus on the kleptoplastids. For choreotrichids, transmission electron microscopic data are also scarce; Rimostrombidium lacustre [reported as Strobilidium velox by Grim (1987)] and some tintinnids (Laval 1972, Hedin 1975, Laval-Peuto 1975, Hedin 1976, Laval-Peuto et al. 1979, Sokolova and Gerassimova 1984, Sokolova et al. 1986) have been investigated.

Only detailed comparative studies will provide insights which allow splitting the non-monophyletic family Strombidiidae and the genus Strombidium. Simultaneously, features might emerge that evolved specifically in species that entered freshwater, an important step that occurred independently in various groups of protists. Hence, the pelagostrombidiid ciliate Limnostrombidium viride (Stein, 1867) Krainer, 1995 inhabiting freshwater is ultrastructurally investigated here, using transmission electron microscopy, scanning electron microscopy, and the freeze-fracture technique. This species is comparatively well-known concerning the morphology of cell and resting cyst and its autecology (Foissner et al. 1991, Krainer 1995, Foissner et al. 1999, Müller and Wünsch 1999). Penard (1920) and Kahl (1932) described rather detailed the ring-canal with a ventral interruption in live cells; the former author also provided line drawings of the organelle depicting its placement. In L. viride, the formation of the opisthe's membranellar zone was studied by Kormos and Kormos (1958) and also by Krainer (1995) in protargol-stained cells; in general, Pelagostrombidiidae form the new adoral membranelles in the neoformation organelle.

In the present study, the majority of apomorphies characterising the genus Limnostrombidium have been investigated ultrastructurally for the first time, e.g., the club-shaped girdle cilia, the ring-canal, and the tubeshaped neoformation organelle. Additionally, the sparse data available on the oral apparatus, cell cortex, nuclear apparatus, and the extrusomes in oligotrichids are augmented by the findings on $L$. viride.

\section{MATERIALS AND METHODS}

\section{Sampling and cultivation}

Limnostrombidium viride was collected from a private garden pond (approximately $12 \mathrm{~m}^{2}$ in size and $80 \mathrm{~cm}$ in depth) in the village of Hirrlingen near the city of Rottenburg am Neckar, Germany, in March 1995. The cells were isolated with a micropipette, grown in Pringsheim solution (Pringsheim 1946), and fed with the chlorophyte Chlorogonium elongatum and the cryptomonad Cryptomonas spec. The non-axenic cultures were kept at room temperature (about $21^{\circ} \mathrm{C}$ ) for about three years.

\section{Electron microscopy}

For scanning electron microscopy (SEM), best fixation results were obtained with the osmium tetroxide/mercury solution (Párducz 1967). The preserved cells were washed in sodium cacodylate buffer and stored up to several weeks in $70 \%$ ethanol. Later, the cells were critical-point-dried, sputter-coated with gold/palladium, and viewed in a Cambridge Stereoscan 250 MK2 (Cambridge Instruments, Cambridge, UK).

For transmission electron microscopy (TEM), cells were fixed in a solution made of $1 \%$ glutaraldehyde and $1 \%$ osmium tetroxide in $0.1 \mathrm{M}$ phosphate buffer $\mathrm{pH} 6.1$ for $20 \mathrm{~min}$ on crushed ice. Subsequently, the cells were washed twice in $0.1 \mathrm{M}$ sodium cacodylate buffer and dehydrated in $70 \%$ ethanol. Then, they were bloc-stained over night with saturated uranyl acetate in $70 \%$ ethanol, further dehydrated, and embedded in Epon 812. Thin sections were post-stained with Reynolds lead solution and viewed in a Siemens Elmiskop 1A. To select appropriate cells for thin sectioning, Toluidine Blue-stained semithin sections $(0.5-1 \mu \mathrm{m})$ were used (Trump et al. 1961).

For freeze-fracture, cells were fixed in $1 \%$ glutaraldehyde in $0.05 \mathrm{M}$ cacodylate buffer for $20 \mathrm{~min}$ at room temperature and subsequently washed and stored in $30 \%$ glycerol. Freeze-fracture replicas were prepared in a Balzers BAF 301 freeze-fracture apparatus (Balzers AG, Liechtenstein), following the routine procedures described in Bardele (1983). The direction of the shadow-casting is indicated by an arrowhead in the P-face micrographs (Figs 5B, C, 7B, 10A).

\section{Terminology}

The numbering of the microtubule triplets following Grain (1969) is restricted to the somatic kinetids. Owing to the unknown homology of the fibrillar associates of the adoral membranelles, 
they are described without referring to a triplet numbering. The naming of membranelles follows Agatha and Riedel-Lorjé (2006), the naming of somatic ciliary rows follows Agatha (2004a), and that of the ultrastructure of the oral apparatus follows de Puytorac and Grain (1976), Lynn (1988), as well as Bakowska and JerkaDziadosz (1978). For the comparison of the oral polykinetids, it is important to keep in mind that the right/proximal end of a polykinetid in euplotids and hypotrichs corresponds to the anterior end of a collar polykinetid in oligotrichids, choreotrichids, and halteriids; the numbering of the basal body rows in the polykinetids follows Bakowska and Jerka-Dziadosz (1978), i.e., the proximalmost row is the first row of the organelle. To further facilitate comparison, the cells are always seen from outside. According to the hypothesis of Agatha (2004a), the somatic kineties of oligotrichids are homologous to the longitudinal rows on the dorsal side of euplotids and hypotrichs; hence, the left of the paired basal bodies (dikinetids) in the oligotrichid girdle kinety are equivalent to the previously anterior basal bodies.

\section{RESULTS}

General appearance in the SEM (Figs 1A-C, 3A, 4A, 9A, B)

Limnostrombidium viride is obovoidal and measures about $50-70 \times 40-45 \mu \mathrm{m}$ in the scanning electron micrographs. The anterior cell portion is occupied by a conspicuous zone of adoral membranelles, which forms a C-shaped pattern around a spoon-shaped apical protrusion (Figs 1A, B). The adoral membranelles are used for both locomotion and collecting food items. The zone comprises a distal portion with about 16 large collar membranelles and a proximal portion with 12-14 small buccal membranelles. The collar membranelles are triangular and up to $23 \mu \mathrm{m}$ long; frequently, their inner cilia are separated from the outer ones and are bent towards the peristomial field (Fig. 3A). They have frayed tips and are about $5 \mu \mathrm{m}$ apart from each other, but they are not separated by distinct ridges. The buccal zone portion is continuous with the collar portion and extends obliquely, terminating distinctly above mid-body. The buccal membranelles are clearly distinguished from the collar membranelles by the length of their cilia (up to about 12-14 $\mu \mathrm{m}$ ) and width of their polykinetids. A buccal lip, the ventral continuation of the apical protrusion, borders the peristomial field on its right side and bears on its inner wall the endoral membrane, which is usually not visible probably because it is covered by a membranous sheet (see below).

In the equatorial cell portion, the seemingly closed, horizontally orientated girdle kinety extends in a shallow furrow. It comprises two types of alternating cilia: clearly recognisable club-shaped ones and inconspicuous condylocilia (Figs 1C, 4A). The ventral kinety extends in a shallow, longitudinal furrow, which commences more or less directly posteriorly to the girdle kinety underneath the buccal vertex and ends subterminally. It has associated 13-18 clearly recognisable, normally shaped (rod-shaped) cilia (Figs 1A-C).

A bulge with the stripe of extrusome attachment sites extends just above the girdle kinety (Figs 1A, C, 9A, B). Posterior to the buccal vertex, the stripe of extrusome attachment sites is interrupted by the elliptical opening of the neoformation organelle (Figs 1A, C), a permanent subsurface structure in which the opisthe's membranellar zone forms during cell division. The entire cell surface is covered by minute granules of unknown nature (Fig. 1C). Resting cysts were not found in the culture.

\section{Oral ciliature (Figs 1B, 2A-E, 3A-D)}

The adoral membranelles are of the paramembranelle type with square-packed basal bodies (de Puytorac and Grain 1976) and are enclosed by a perilemma (Fig. 2D), except for their frayed tips (Figs 1B, 3A). The collar polykinetids comprise three equally long rows composed of about 21 basal bodies each; all basal bodies are ciliated. The buccal polykinetids also comprise three rows of basal bodies, of which the third row is, however, shortened by about one third at its distal end. Additionally, the width of the polykinetids decreases from the distal to the proximal end of the zone portion; accordingly, the distal buccal membranelles comprise two rows with about 22 basal bodies and a third row with about 14 basal bodies, whereas the proximal membranelles have two rows with eight basal bodies and a third row with three basal bodies only.

In the following, the structure of collar polykinetids is described. The basal bodies of a polykinetid are linked with each other in several ways and at different levels (Figs 2A-C, E). The basal bodies of the first row have associated microtubular ribbons (possibly postciliary ribbons) at the level of the cartwheel. These ribbons extend towards the cell surface where they curve posteriorly, extending parallel to the polykinetid's main axis, forming intermembranellar fibres (Fig. 2C). The basal bodies of the third row have associated microtubular ribbons (possibly transverse ribbons), which are indistinct as they are composed of only about three microtubules each. Adjacent membranelles are linked by microtubules (possibly lateral microtubular ribbons), which commence in electron-dense material of the third 

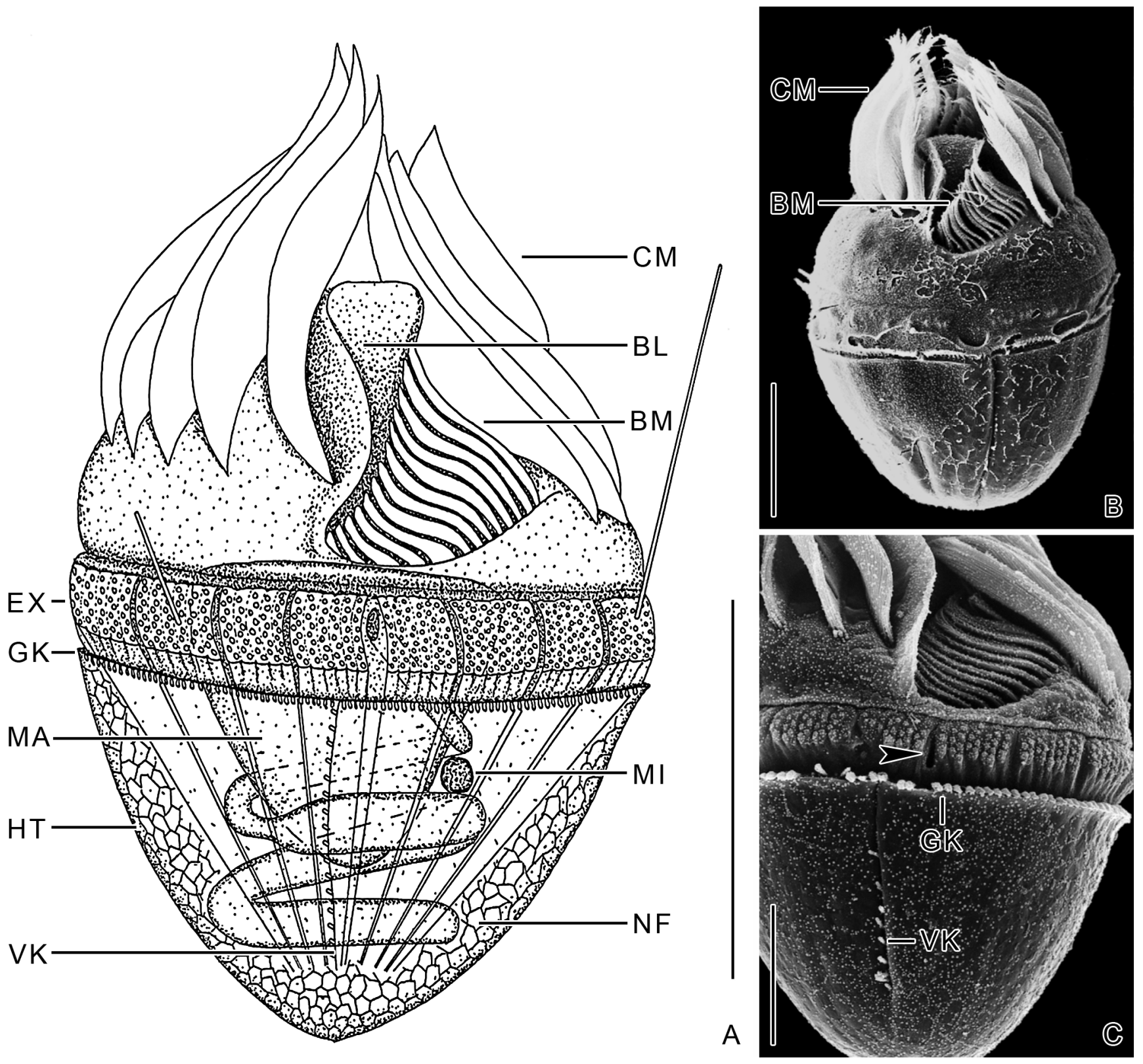

Fig. 1. Limnostrombidium viride (A, schematic line drawing combining data from scanning and transmission electron microscopy; B, C, scanning electron micrographs). (A) General morphology. Note that the polygonal platelets of the hemitheca are only depicted in the cell periphery to show the more centrally located organelles. For the sake of clarity, the course of the neoformation organelle is somewhat stretched. (B, C) Ventral view and detail of ventral side. The arrowhead (C) marks the opening of the neoformation organelle in the stripe of extrusome attachment sites. BL, buccal lip; BM, buccal membranelles; CM, collar membranelles; EX, stripe of extrusome attachment sites; GK, girdle kinety; HT, hemitheca; MA, macronucleus; MI, micronucleus; NF, neoformation organelle; VK, ventral kinety. Scale bars: $30 \mu \mathrm{m}$ (A), $20 \mu \mathrm{m}$ (B), $10 \mu \mathrm{m}$ (C).

row and extend parallel to the cell surface (not shown). Parasomal sacs could not be identified unequivocally.

The endoral membrane commences at the level of the first (distalmost) collar membranelle's lower margin, extends in a longitudinal furrow on the inner wall of the buccal lip, and terminates near the buccal vertex (Figs 3A-D). Its proximal portion is covered by a cytoplasmic fold and the distal portion by several membranous layers, probably perilemma (see below). The endoral consists of a single row of ciliated basal bod- 


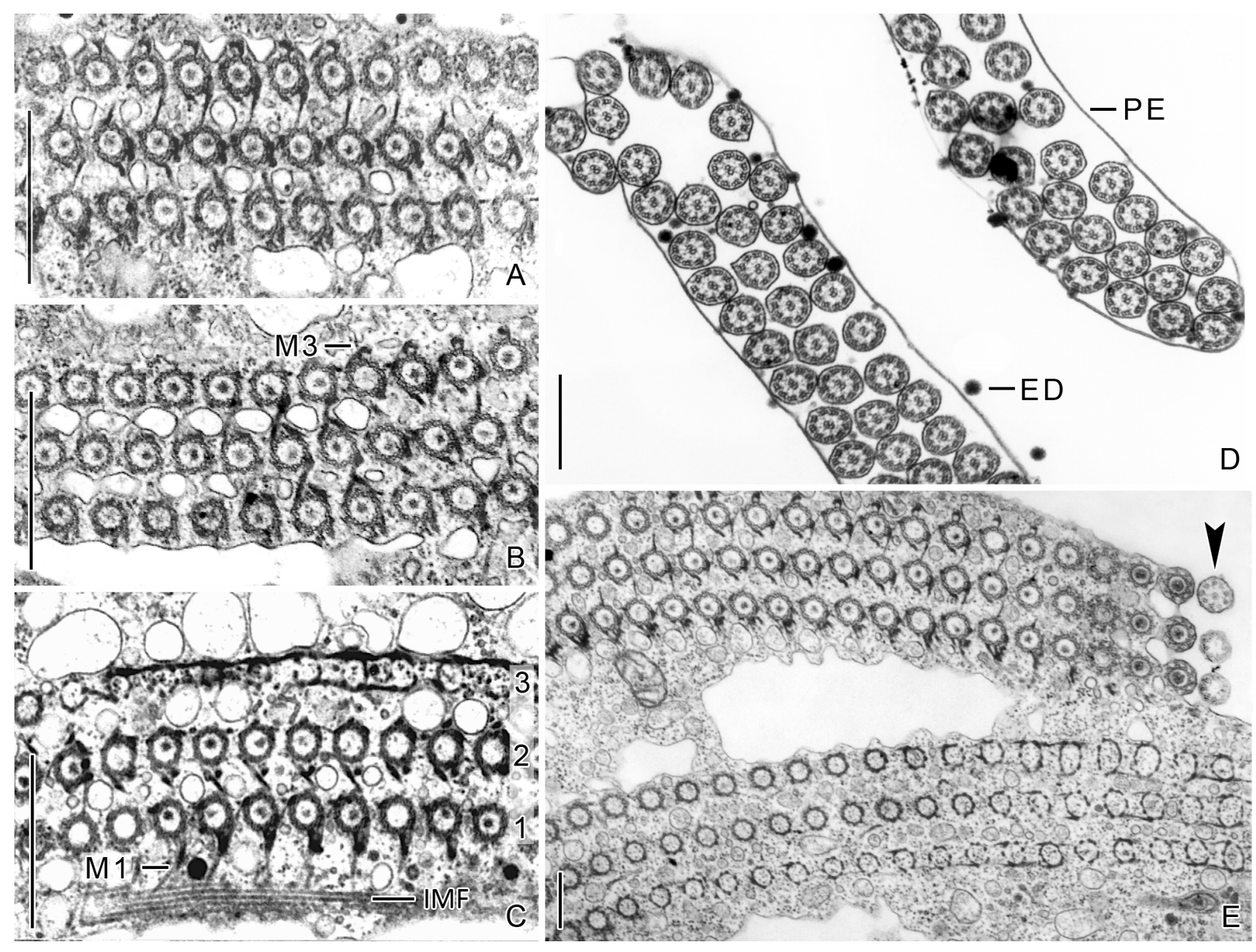

Fig. 2. Transmission electron micrographs of collar membranelles in Limnostrombidium viride. Their anterior ends are directed to the left. (A-C) Transverse sections at different planes showing the various connections between the basal bodies of an individual membranelle and the microtubules extending into the cytoplasm. (D) The axonemes of the individual cilia are enclosed by the cell membrane, while all cilia of a membranelle are additionally surrounded by the perilemma. (E) Transverse sections of two polykinetids at the level of the basal bodies. The last file of the upper adoral membrane has associated short ciliary stubs only (arrowhead). 1-3, rows 1-3; ED, electron-dense bodies; IMF, intermembranellar fibre; M1, microtubular ribbons at row 1; M3, microtubular ribbons at row 3; PE, perilemma. Scale bars: $1 \mu \mathrm{m}$ $(\mathrm{A}-\mathrm{C}), 0.5 \mu \mathrm{m}(\mathrm{D}, \mathrm{E})$.

ies, which have the same orientation and are linked by oblique, electron-dense structures (Fig. 3D); thus, it matches the definition of a stichomonad polykinetid by de Puytorac and Grain (1976). The tips of the cilia have modified axonemes with a reduced number of peripheral microtubular doublets (Fig. 3C). Three types of microtubules are associated with the endoral basal bodies: (i) microtubular ribbons which originate from the right side of the endoral (seen from inside the buccal cavity) and extend obliquely anteriorly into the buccal lip; (ii) bifurcate microtubular ribbons which commence on the left side of the endoral and extend obliquely posteriorly parallel to the dorsal wall of the buccal cavity; and (iii) possibly nematodesmata which start at the proximal ends of the basal bodies and extend through the base of the buccal lip towards the cytostome (Fig. 3B). Kinetodesmal fibrils and parasomal sacs are apparently absent.

\section{Somatic ciliature (Figs 1A-C, 4A, B, 5A-E, 6A, B)}

The girdle kinety extends in an equatorial furrow and along the anterior margin of the hemitheca (Figs 

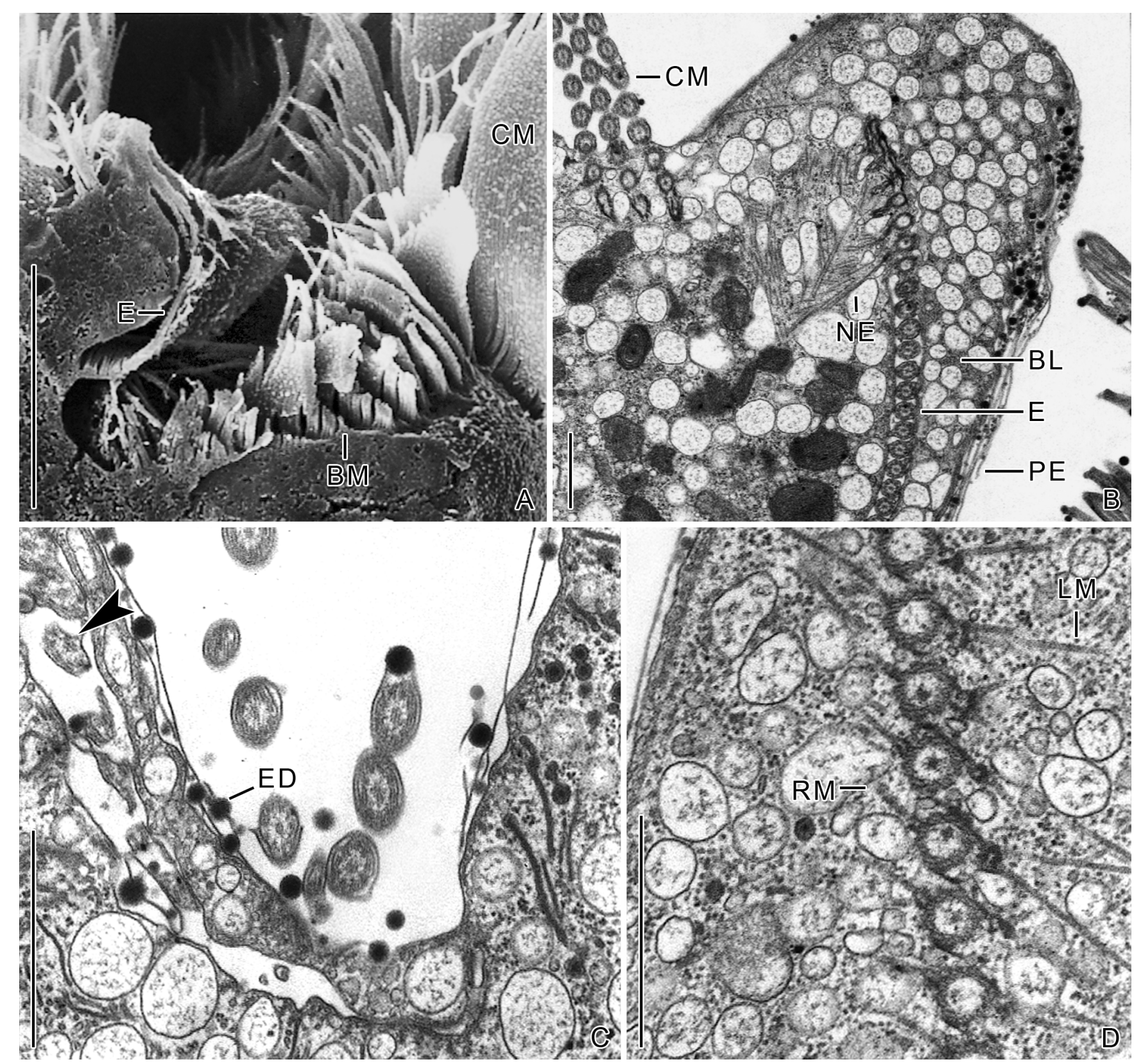

Fig. 3. Oral ciliature of Limnostrombidium viride in the scanning (A) and transmission electron microscopes (B-D). (A) Proximal portion of the adoral zone of membranelles. The endoral membrane is usually covered by a cytoplasmic fold and a membranous sheet (probably perilemma). (B) Longitudinal section of the buccal lip and endoral membrane in ventral view. Note the numerous vesicles with fluffy content of unknown nature in the anterior cell half and especially in the buccal lip. The perilemma forms stacks in the buccal cavity, while it otherwise covers the cell only with a single layer. (C) Longitudinal section of the buccal vertex near the cytostome. The distal ends of the endoral cilia have modified axonemes (arrowhead), i.e., they have a reduced number of peripheral microtubular doublets. Some cilia of the buccal membranelles and the multiple membranes are also recognisable. (D) Transverse section of the basal bodies of the endoral membrane (seen from inside the buccal cavity). BL, buccal lip; BM, buccal membranelles; CM, collar membranelles; E, endoral membrane; ED, electron-dense bodies; LM, bifurcated left microtubular ribbons; NE, possibly nematodesmata; PE, perilemma; RM, right microtubular ribbons. Scale bars: $10 \mu \mathrm{m}(\mathrm{A}), 1 \mu \mathrm{m}(\mathrm{B}-\mathrm{D})$. 

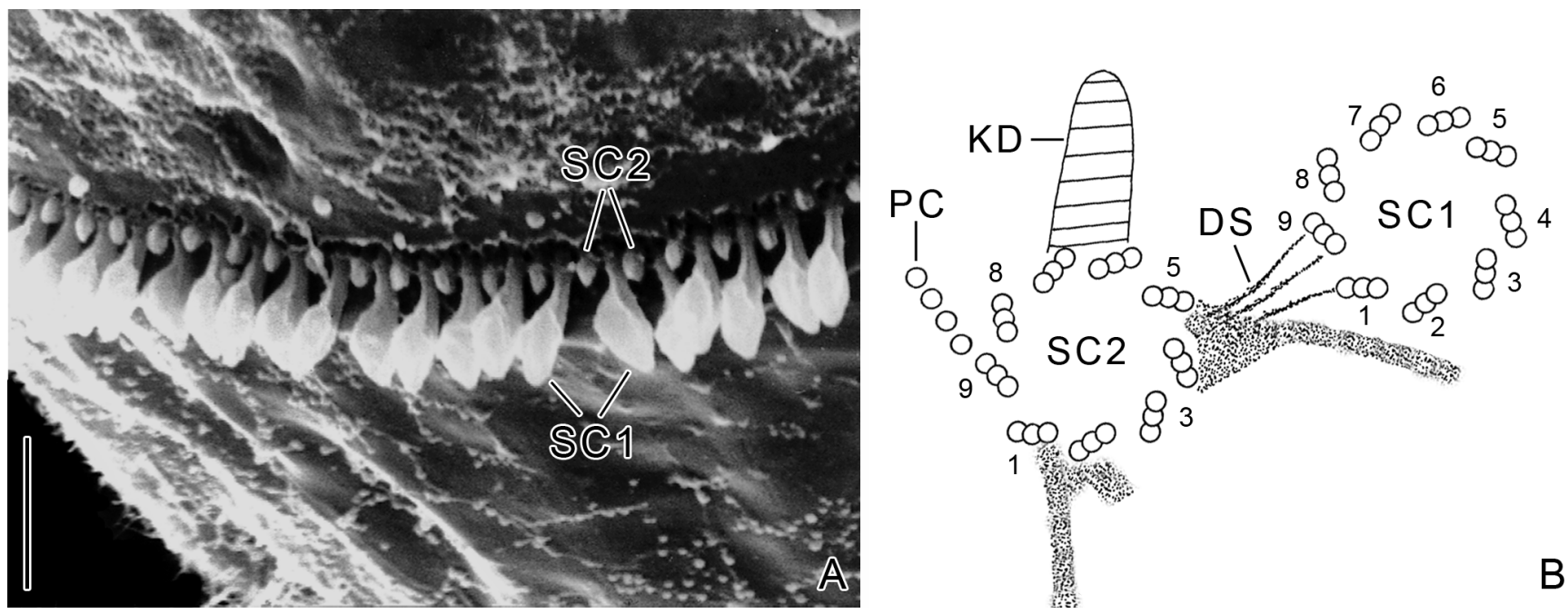

Fig. 4. Girdle kinety of Limnostrombidium viride (A, scanning electron micrograph; B, scheme of dikinetid). (A) Detail of kinety showing the two alternating types of girdle cilia. (B) Dikinetid with the associated structures; the presence of a transverse ribbon is uncertain. Numbering of the triplets (1-9) follows the "Grain convention", but is somewhat uncertain, as the triplets are difficult to identify. The scheme bases on numerous transmission electron micrographs (not shown). DS, desmose; KD, kinetodesmal fibril; PC, postciliary microtubular ribbon; SC1, club-shaped cilia of left dikinetidal basal bodies (originally anterior ones); SC2, condylocilia of right dikinetidal basal bodies (originally posterior ones). Scale bar: $2 \mu \mathrm{m}$.

1A-C, 4A, 5D). It is composed of dikinetids slightly anti-clockwise inclined to the kinety axis (Figs 4B, 5E). The cilia are enclosed by perilemma (Fig. 5A). The left basal body is ordinarily orientated and forms an angle of about $20^{\circ}$ with the right basal body (Fig. 5A); both are connected by a desmose (Figs 4B, 5E). Electrondense core granules are not clearly recognisable. Postciliary microtubules originate near triplet 9 of the right basal body, which also has a short kinetodesmal fibril near triplets 6 and 7 (Figs 4B, 5E). Neither overlapping postciliary microtubular ribbons nor lasiosomes are recognisable. The presence of transverse microtubular ribbons is not clear. A postciliary microtubule originating near the left basal body and a parasomal sac are not visible. Near triplets 1 and 2 of the right basal body a hook-shaped, electron-dense structure originates, of which the right, long branch (possibly a microtubular ribbon) extends posteriorly. A further electron-dense structure, possibly separate from the desmose, extends tangentially near triplets 1 and 2 of the left basal body.

A clearly recognisable cilium about $2 \mu \mathrm{m}$ long with a common " $9 \times 2+2$ "-axoneme is associated with each left dikinetidal basal body (Figs 5A, D, E). It is clubshaped because of electron-dense material on the right side of the axoneme (Figs 4A, 5A, D). Freeze-fracture micrographs of the cell membrane of these cilia show a conspicuously high density of orthogonally arranged intramembranous particles in the P-face (Figs 5B, C). Each right dikinetidal basal body has associated a condylocilium about $0.5 \mu \mathrm{m}$ long with a short, atypical axoneme containing several apparently disorganised granules (Figs 4A, 5A).

The ventral kinety extends in a longitudinal furrow formed by the polygonal cortical platelets (Figs 1A-C, $6 \mathrm{~A}, \mathrm{~B})$. It is composed of dikinetids, in which the posterior basal bodies form an angle of about $30^{\circ}$ with the ordinarily orientated anterior ones. The anterior dikinetidal basal bodies have associated clearly recognisable, about $1.3 \mu \mathrm{m}$ long, normally shaped cilia, while the posterior basal bodies bear only ciliary stubs, which extend underneath the perilemma and are usually not visible in scanning electron micrographs.

Cortex (Figs 2D, 3B, C, 5A, D, 6A, B, 7A-C, 9C, D, $11,12 \mathrm{~A}, \mathrm{D})$

The whole cell is enclosed by perilemma, a layer resembling the cell membrane in thickness, but of unknown chemical composition. It is studded with electron-dense bodies of unknown function and nature (Figs 2D, 3B, C, 5A, 6A, B, 7C, 9C, D, 11, 12A, D), to a smaller extend they are also seen underneath the perilemma; they are probably identical with the regularly 

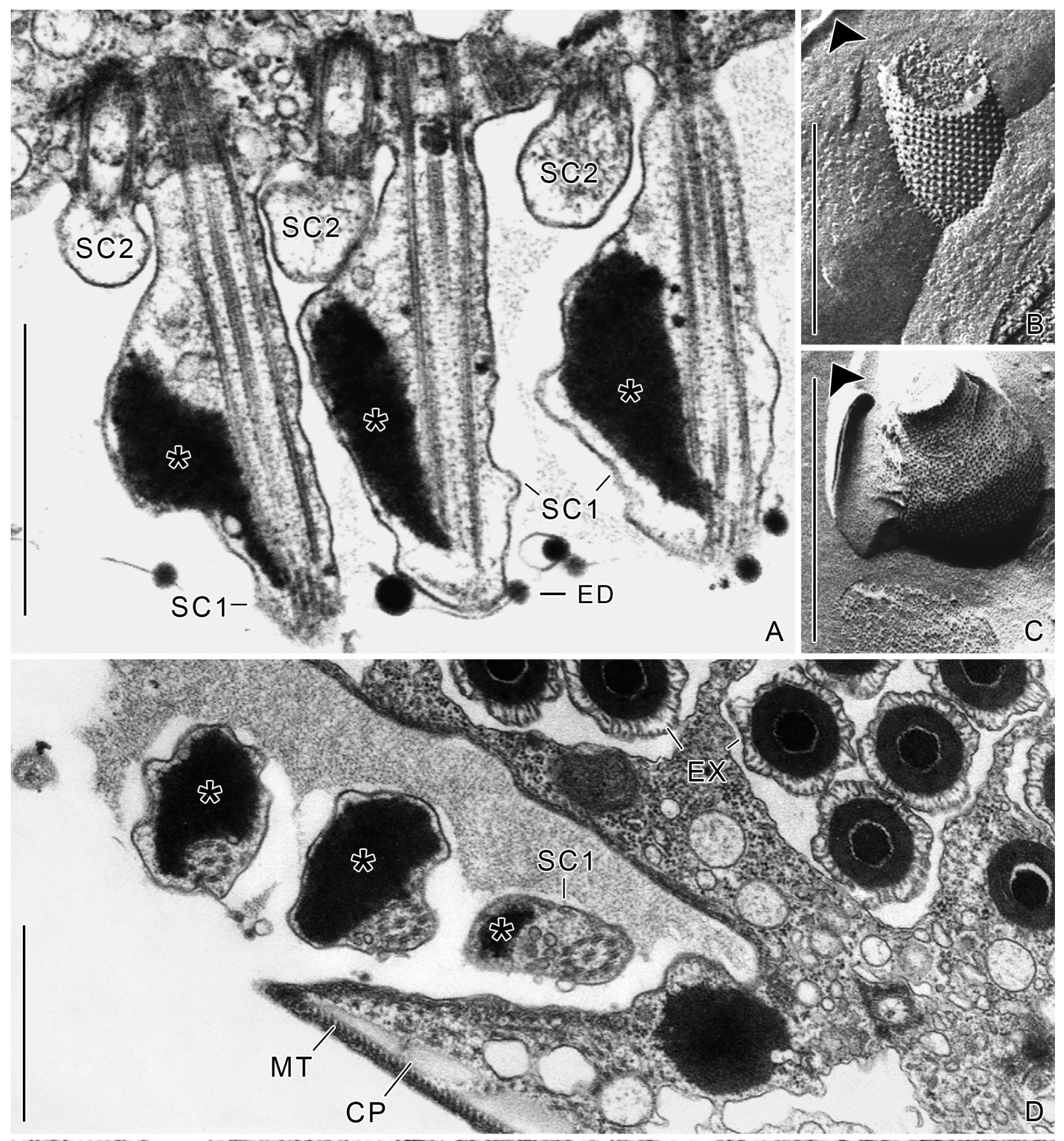

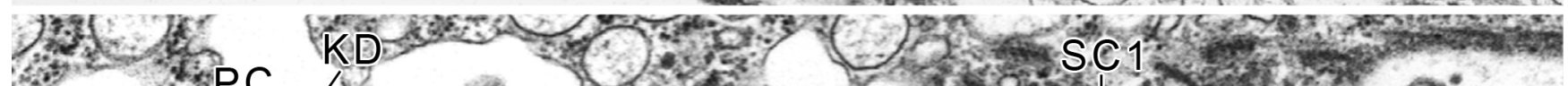

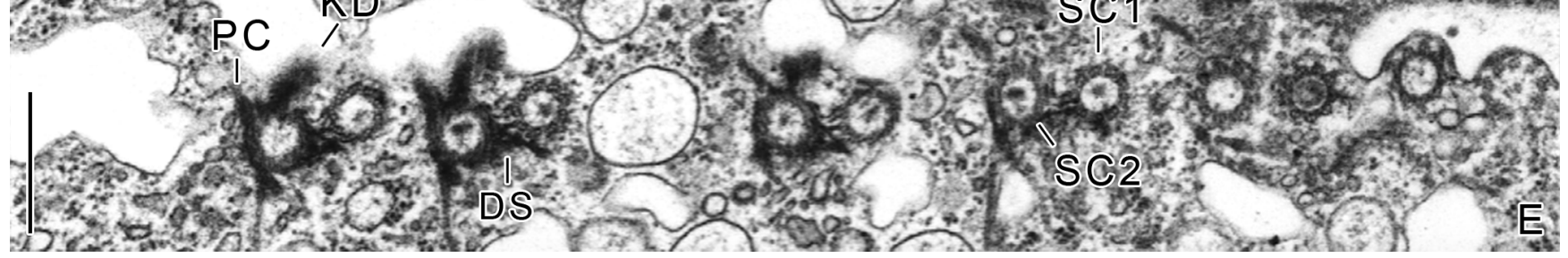


distributed granules seen on the cell surface in scanning electron micrographs (Figs 1C, 4A, 9A, B). Minute vesicles often found underneath the cell membrane probably represent pellicular alveoli (Figs 7B, C); a layer of densely spaced (distance about $10 \mathrm{~nm}$ ), longitudinally orientated microtubules follows (Figs 5D, 6B, 7A-C).

In the proximal portion of the buccal cavity near the cytostome, membranes (probably perilemma) form stacks of up to five layers, which show an exceptionally dense arrangement of the electron-dense bodies (Figs 3B, C). The peripheral cytoplasm of the buccal lip is full of vesicles with unknown fluffy content (Figs 3B-D).
In the cell portion posterior to the girdle kinety, highly transparent polygonal cortical platelets are subjacent to the longitudinal microtubules and form the so-called hemitheca, which is interrupted ventrally by a shallow furrow containing the ventral kinety (Fig. 6B). The platelets, which are apparently not surrounded by unit membrane, measure $1-2 \mu \mathrm{m}$ in diameter and are usually $0.3-0.6 \mu \mathrm{m}$ thick but become gradually thinner towards the hemitheca margins (Figs 5D, 6B). The gaps between the platelets are usually less than $0.1 \mu \mathrm{m}$ broad, except for rather regularly and horizontally orientated ones about $130 \mathrm{~nm}$ wide. In the regions of these broadened gaps, the highly abundant particles of the

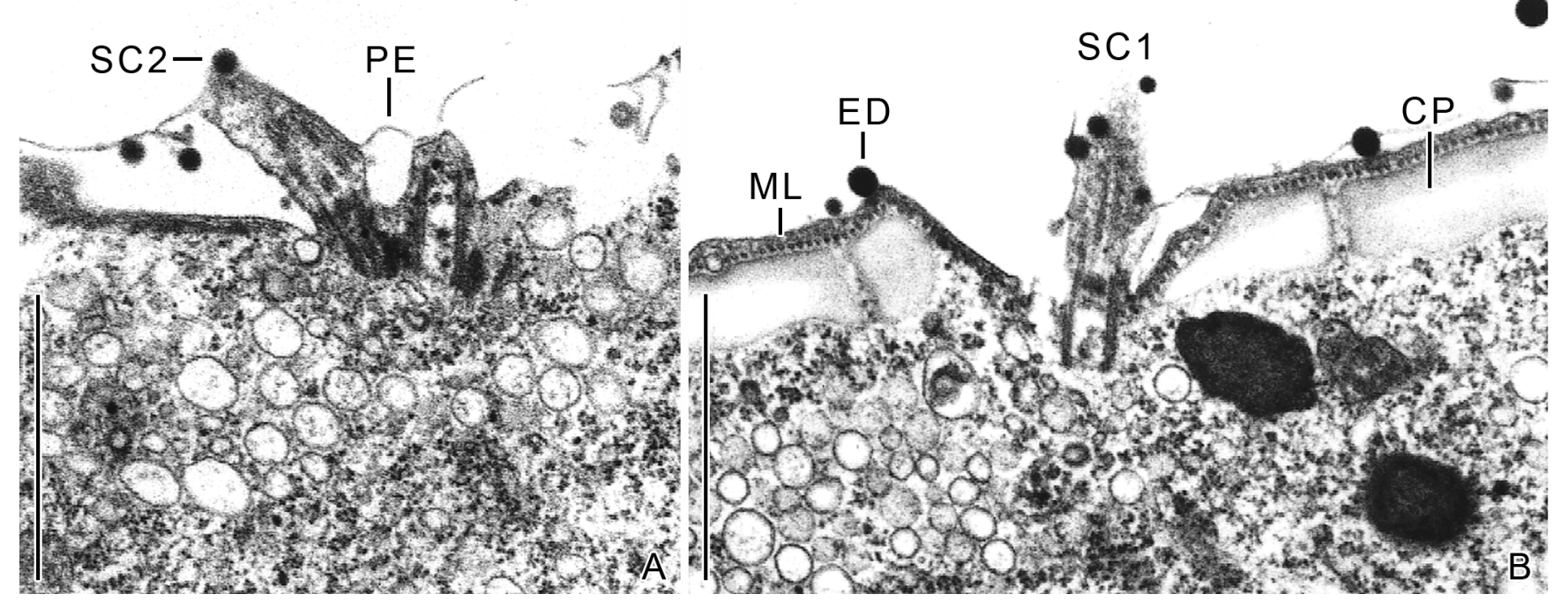

Fig. 6. Ventral kinety of Limnostrombidium viride in the transmission electron microscope. (A) Longitudinal section of a dikinetid showing the diverging basal bodies. A perilemma covers the cell surface. (B) Transverse section showing a dikinetid in the longitudinal furrow laterally bordered by the cortical platelets of the hemitheca. CP, cortical platelets; ED, electron-dense bodies; ML, cortical microtubular layer; $\mathrm{PE}$, perilemma; SC1, anterior dikinetidal cilium; SC2, posterior dikinetidal cilium. Scale bars: $1 \mu \mathrm{m}$.

Fig. 5. Girdle kinety of Limnostrombidium viride (A, D, E, transmission electron micrographs; B, C, transmission electron micrographs of freeze-fracture replica). (A) Longitudinal section. The cilia associated with the left dikinetidal basal bodies are club-shaped because of electron-dense material (asterisks) on the right side of the axonemes. The basal bodies of a dikinetid are not parallel as indicated by the oblique section of each right basal body. Besides the cell membrane, the cilia are enclosed by the perilemma (here only represented by electron-dense bodies). (B, C) Freeze-fracture replica of the club-shaped portion of the left cilia. The intramembranous particles are densely arranged in orthogonal rows. (D) Transverse section showing the girdle kinety between the stripe of extrusome attachment sites and the hemitheca. Only the longer club-shaped left cilia with their electron-dense material (asterisks) are visible. (E) Tangential section. The dikinetidal basal bodies are connected by a desmose. The right basal body has associated a postciliary ribbon and a kinetodesmal fibril. Further electron-dense structures near the posterior margin of the dikinetids are recognisable (cp. Fig. 4B). CP, cortical platelets; DS, desmose; ED, electron-dense bodies; EX, extrusomes; KD, kinetodesmal fibrils; MT, cortical microtubular layer; PC, postciliary microtubular ribbon; PE, perilemma; SC1, club-shaped cilium of left dikinetidal basal body; SC2, condylocilium of right dikinetidal basal body. Scale bars: $1 \mu \mathrm{m}$ (A, C, D), $0.5 \mu \mathrm{m}(\mathrm{B}, \mathrm{E})$. 


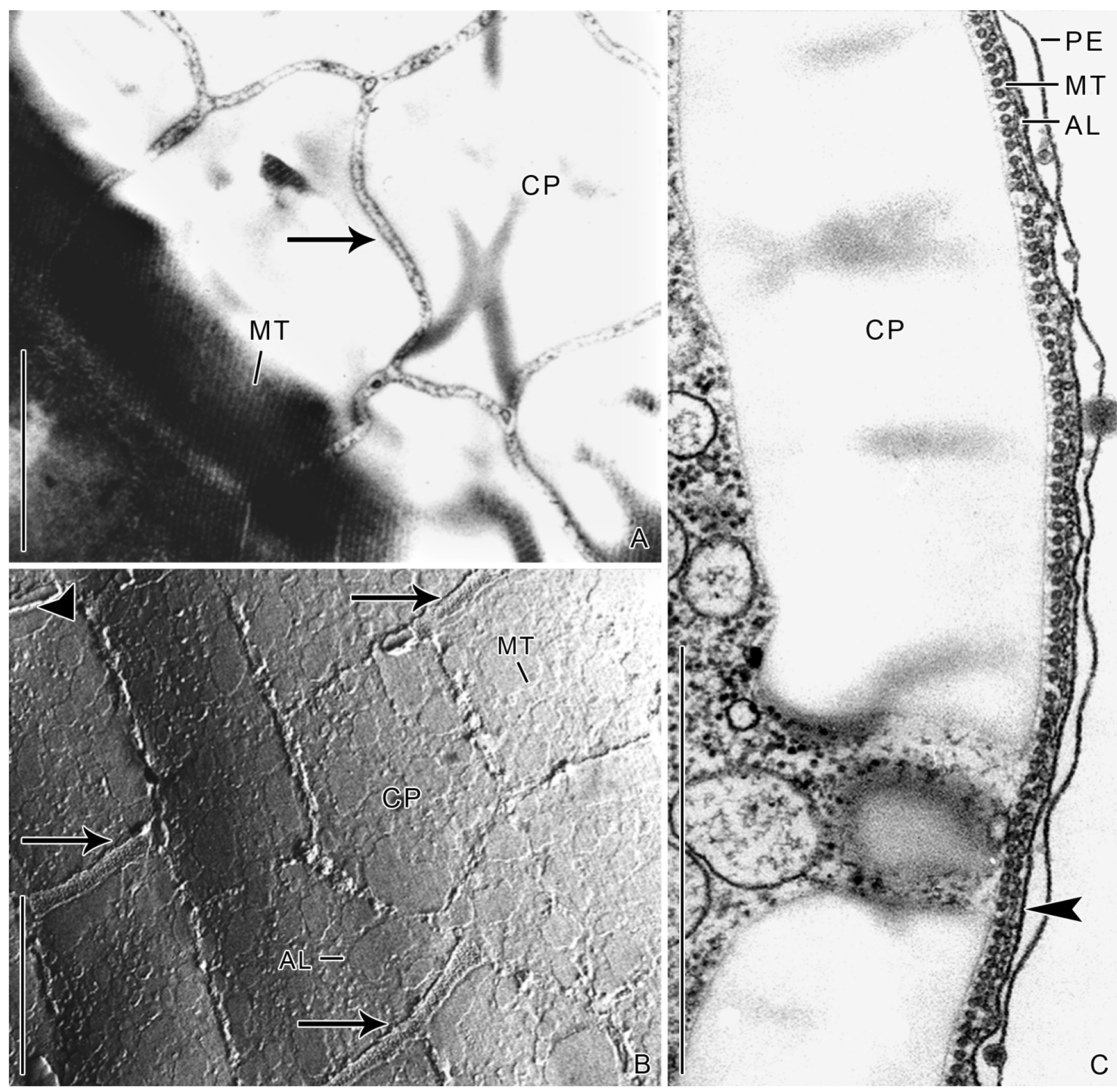

Fig. 7. Hemitheca of Limnostrombidium viride in the transmission electron microscope. (A) Tangential section showing the seams (arrow) between the polygonal cortical platelets, which are covered by the layer of longitudinal microtubules. (B) Freeze-fracture replica showing the seams between the polygonal platelets, the layer of longitudinally orientated microtubules, the alveoli, and remnants of the cell membrane with its densely arranged particles (arrows). (C) Transverse section showing the perilemma with its electron-dense bodies, the alveoli, the layer of longitudinal microtubules, and the polygonal cortical platelets. The arrowhead marks the cell membrane. AL, alveoli; CP, cortical platelets; MT, cortical microtubular layer; PE, perilemma. Scale bars: $1 \mu \mathrm{m}$. 

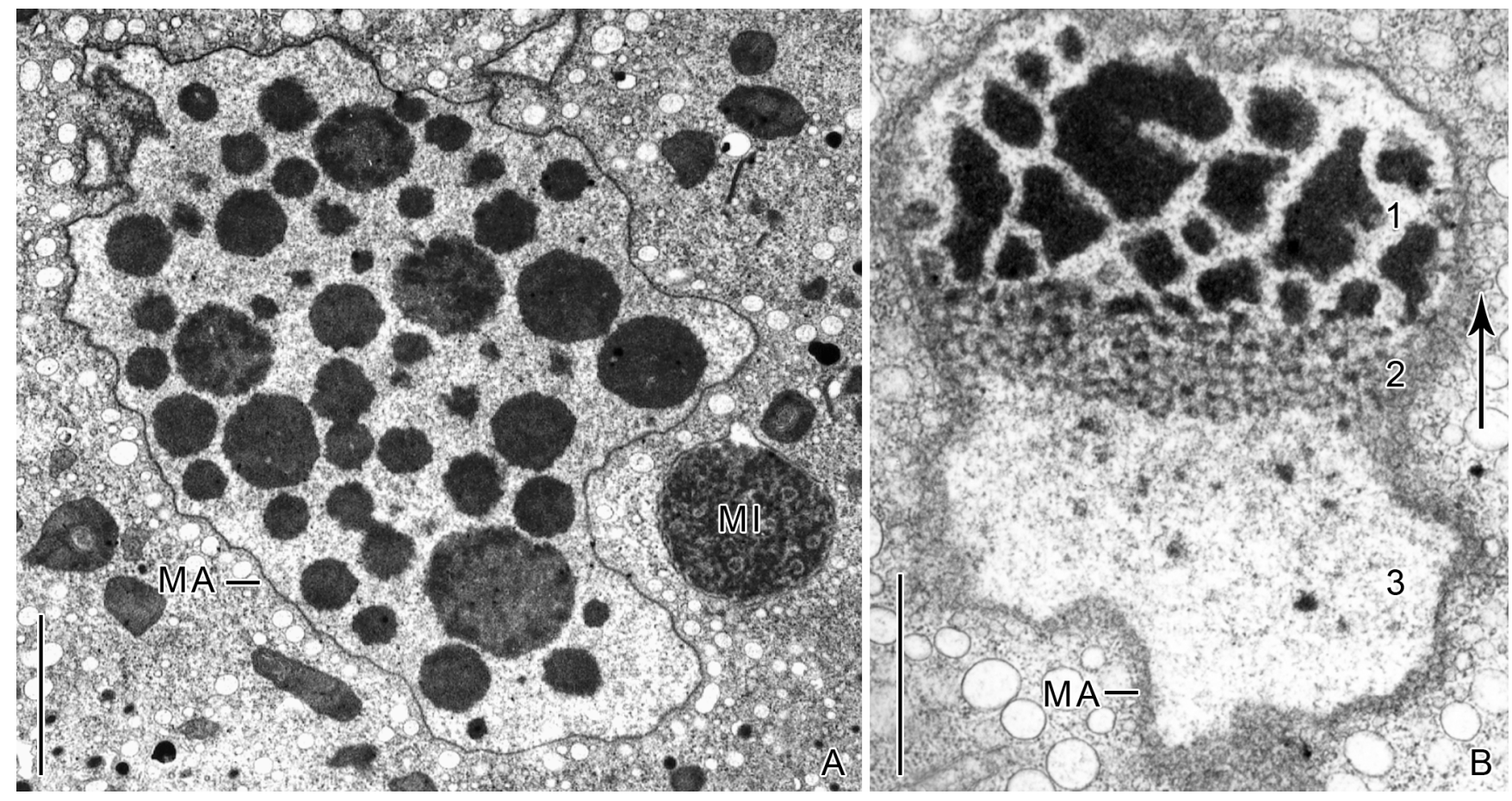

Fig. 8. Nuclear apparatus of Limnostrombidium viride in the transmission electron microscope. (A) Interphase state showing the micronucleus in an indentation of the macronucleus, which has an irregular surface and contains numerous electron-dense inclusions, probably nucleoli. (B) A macronucleus showing the replication band. The arrow indicates the migration direction of the replication band. 1, zone of typical macronuclear structure; 2, zone characterised by protein and RNA production; 3, bright zone with beginning biosynthesis and DNA replication; MA, macronucleus; MI, micronucleus. Scale bars: $2 \mu \mathrm{m}$.

cell membrane are recognisable in the freeze-facture replica (Fig. 7B).

\section{Nuclei (Figs 1A, 8A, B)}

The macronucleus is in the centre of the cell and somewhat anteriorly to the stripe of extrusome attachment sites. Its shape is slightly variable, namely broadly ellipsoidal to globular. It measures up to $20 \mu \mathrm{m}$ across, has an irregular surface, and contains numerous electron-dense globules probably nucleoli (Fig. 8A). A single distinct replication band traverses the macronucleus just before cell division (Fig. 8B). One, rarely two micronuclei are adjacent to the macronucleus (Fig. 8A). Dividing micronuclei display a long intranuclear stem body made of microtubules (not shown).

\section{Extrusomes (Figs 1A-C, 5D, 9A-D, 10A-C)}

The extrusomes of oligotrichids are often called trichites; their extrusive nature could be documented (Figs 9A, D). The organelles insert in a low, about $8 \mu \mathrm{m}$ broad, horizontal bulge between an anterior furrow and the posterior furrow with the girdle kinety (Figs 1A, C, 5D, 9A, B). The extrusomes extend obliquely into the cytoplasm with their pointed ends orientated towards the posterior cell end, forming a funnel-shaped complex (Figs 1A, 9D). The scanning electron micrographs display that the stripe of extrusome attachment sites is about $3 \mu \mathrm{m}$ broad and composed of $12-16$ clusters with five or six double rows of three or four, rarely six extrusomes each (Figs 1A, C, 5D, 9B, C); the clusters are about $0.8 \mu \mathrm{m}$ apart. In the resting state, the extrusomes are about $17 \times 0.5 \mu \mathrm{m}$ in size, acicular in longitudinal section, and circular in cross section (Figs 1A, 5D, 9C, D). Transmission electron microscopy reveals that an extrusome is composed of an electron-dense, slightly hexagonal "core" about $0.19 \mu \mathrm{m}$ across surrounded by a thin electron-light ring and a $0.11 \mu \mathrm{m}$ thick layer of concentric sheets (Figs 5D, 9C). Curved tubules extend radially between the irregular organelle membrane and the extrusome, forming a layer about 0.06 $\mu \mathrm{m}$ thick (Figs 9C, D). The cell cortex is underlain by an electron-dense layer forming caps for the attached 

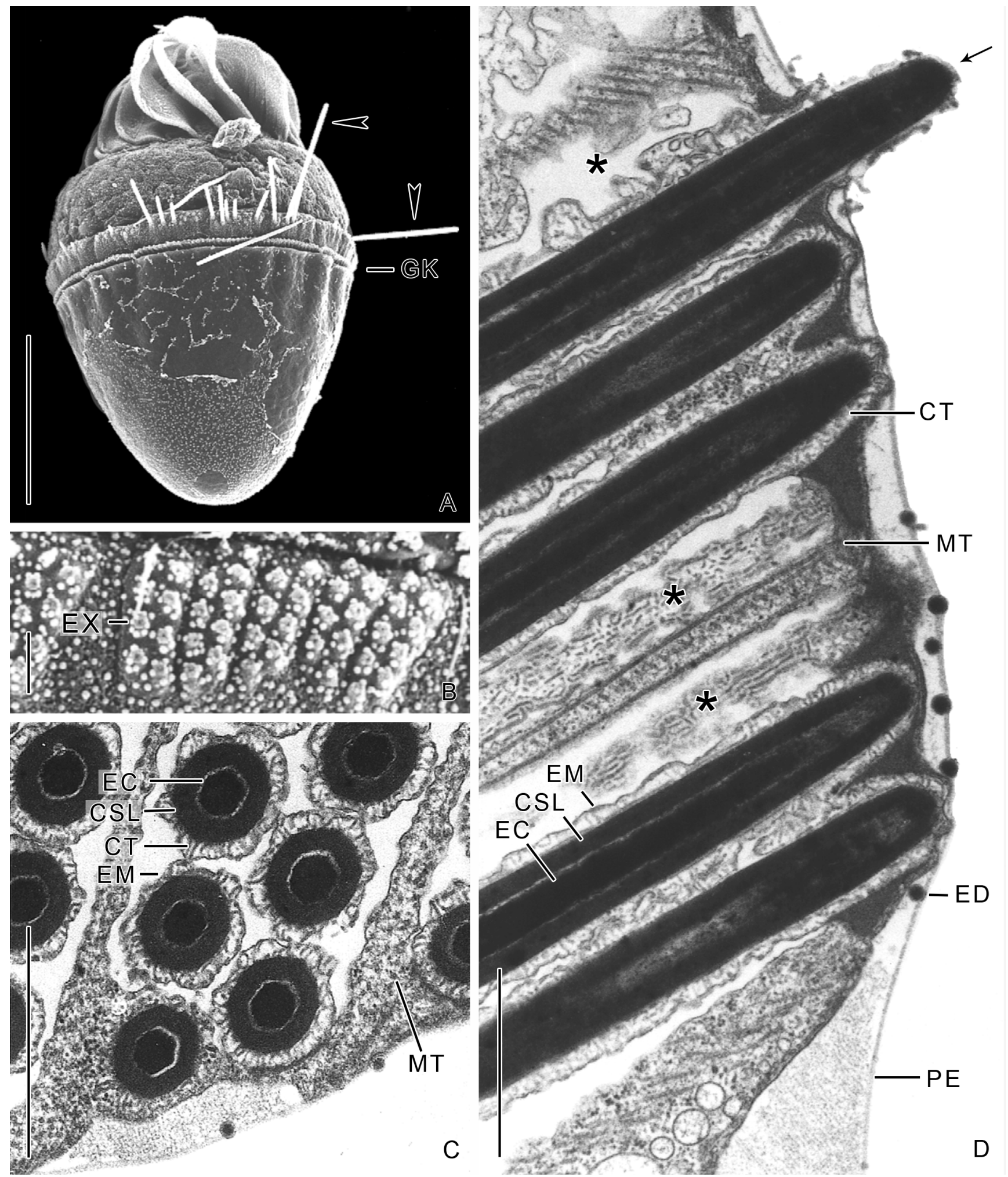

Fig. 9. Extrusomes of Limnostrombidium viride in the SEM (A, B) and TEM (C, D). (A) Lateral view of a cell. Arrowheads mark just ejected extrusomes. (B) Extrusome cluster. (C) Cross section of extrusome stripe. (D) Longitudinal section. One extrusome is just ejected (arrow), four are in the resting state, and three "empty chambers" (asterisks) are the remains of previously ejected extrusomes. CSL, concentric sheet layers; CT, curved tubules; EC, extrusome cores; ED, electron-dense bodies; EM, extrusome membranes; EX, extrusomes; GK, girdle kinety; MT, separating microtubules; PE, perilemma. Scale bars: $20 \mu \mathrm{m}$ (A), $1 \mu \mathrm{m}$ (B-D). 


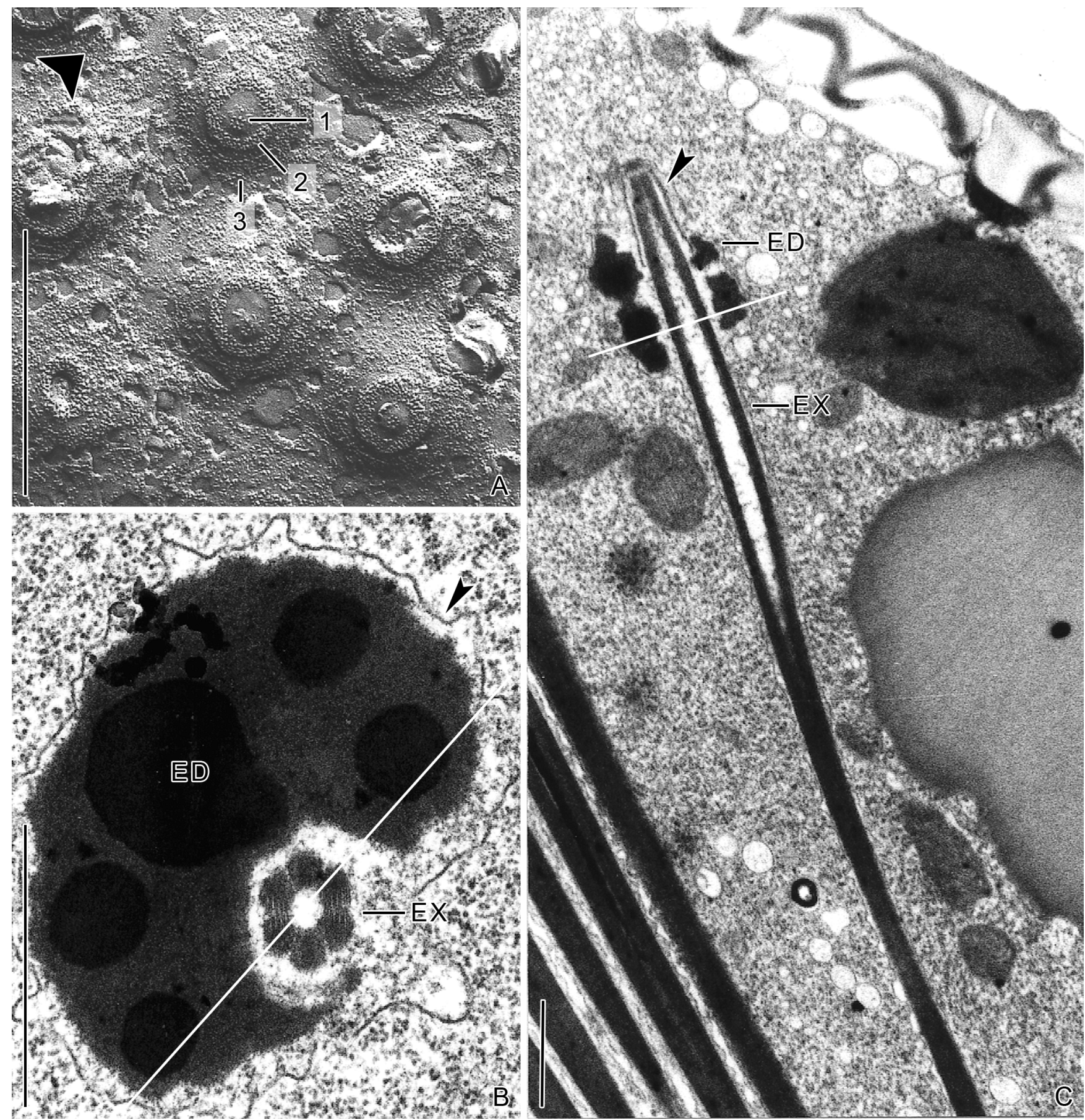

Fig. 10. Extrusome attachment sites (A) and immature extrusomes (B, C) of L. viride in the TEM. (A) Freeze-fracture replica showing the extrusome attachment rosettes. (B, C) Transverse and longitudinal sections; white lines mark corresponding section planes. The extrusome shows in longitudinal section an electron-dense fusiform wall and an electron-light lumen with indistinct transverse stripes. The apical portion of the extrusome is surrounded by an electron-dense structure; both are enclosed by a membrane (arrowheads). The transverse section shows the extrusome to be composed of six electron-dense trapeziums arranged around a bright lumen. 1, attachment rosette with one central and eight peripheral particles; 2, first ring; 3, second ring; ED, electron-dense structure; EX, extrusomes. Scale bars: $1 \mu \mathrm{m}$. 
extrusomes (Figs 9D, 11). The membrane-bound extrusomes are separated by electron-light material and form double rows, which are again surrounded by a membrane (Figs 5D, 9C, D). Such a unit is separated from the adjacent double rows of the same cluster by an about $0.2 \mu \mathrm{m}$ broad stripe of cytoplasm with two or three layers of parallel microtubules, which might originate in the margins of the electron-dense caps (Figs 9C, D). Freeze-fracture micrographs of the extrusome tips show an " $8+1$ "-attachment rosettes with one central and eight peripheral intramembranous particles. The rosette is surrounded by two particle rings (Fig. 10A): a more distinct and broader ring about 50 $\mathrm{nm}$ wide and a ring with less densely spaced particles at the base of the attachment site.

Immature extrusomes enclosed by a membrane are found in the posterior half of the cell. The individual organelle is situated in the indentation of an electrondense structure with very dense, possibly globular inclusions (Figs 10B, C). This structure is kidney-shaped in transverse section, has an uneven surface, and covers the organelle for a certain distance. At this stage, the immature extrusome looks like a flower with six petals arranged around a circular lumen in transverse section (Fig. 10B). While the centres of these six trapezoid structures are electron-dense, their lateral portions show concentric stripes. The lumen displays an indistinct partitioning in longitudinal section (Fig. 10C) and obviously becomes electron-dense in mature state (cp. Figs 10B, C with Figs 5D, 9C, D). Based on the available material, a more detailed description of the immature extrusome and its development is impossible.

\section{Ring-canal (Fig. 11)}

A peculiar structure, the ring-canal, is found. It is an apparently circular, horizontally orientated, up to 0.5 $\mu \mathrm{m}$ wide membranellar tube in the cytoplasm between the anterior furrow and the stripe of extrusome attachment sites (Fig. 11). The posterior portion of the ring membrane is rather horizontally orientated, smooth, and underlain by two layers of perpendicularly orientated microtubules. The anterior portion is vaulted, irregular, and accompanied by many vesicles of different sizes. It had not been checked whether the organelle contracts.

\section{Neoformation organelle (Figs 12A-D)}

The neoformation organelle is a permanent subsurface tube in which the opisthe's zone of adoral membranelles develops; yet, a detailed investigation of stomatogenesis had not been performed.
The organelle opens ventrally in the stripe of extrusome attachment sites (Figs 1A, C) and winds in the posterior cell half (Fig. 12D). It is composed of an unciliated distal portion and a slightly inflated proximal portion with a circular cross section, in which the adoral membranelles form. The extremely short (about $0.5 \mu \mathrm{m}$ ) and incomplete axonemes (the central pair of microtubules is lacking) of the forming cilia stick out into the lumen of the neoformation organelle and are covered with the cell membrane forming the tube (Fig. 12A). Around the tips of the axonemes, many small vesicles of different sizes are found, causing the bulbous appearance of these cilia with diameters of about $1 \mu \mathrm{m}$ (Figs $12 \mathrm{~A}-\mathrm{D})$. Towards the opening of the neoformation organelle, the axonemes become gradually longer (about $1 \mu \mathrm{m})$, possess the typical " $9 \times 2+2$ "-ultrastructure, and are partially arranged in rows (Figs 12B, C).

The unciliated distal tube portion often extends parallel to the ciliated proximal portion (Figs 12A, D). Its lumen is elliptical in cross section (up to about $0.8 \mu \mathrm{m}$ wide) and lined with a layer that is regarded as perilemma because it is studded with electron-dense bodies (Fig. 12A). The subjacent layer is formed by the cell membrane, which has adjacent minute vesicles and tightly packed microtubules resembling the layer of longitudinally orientated ones in the cell cortex.

Mitochondria are extremely abundant in the vicinity of the neoformation organelle. Numerous vesicles $0.07-0.4 \mu \mathrm{m}$ across with electron-dense content of unknown function are exclusively found near the neoformation organelle (Fig. 12C).

\section{DISCUSSION}

\section{Identification of the specimens studied}

The apically located C-shaped zone of adoral membranelles, the hypoapokinetal stomatogenesis in a tube (Foissner 1996), the somatic ciliature comprising two kineties, the hemitheca, the extrusomes (trichites), and the absence of a paroral membrane indicate an affiliation of the species with the oligotrichids. The presence of a neoformation organelle (a permanent subsurface tube) suggests an assignment to the oligotrichid family Pelagostrombidiidae, and the two ciliated somatic kineties, the entirely tubular neoformation organelle, as well as the comparatively short and oblique buccal portion of the adoral zone are typical of the genus Limnostrombidium, which comprises two species, $L$. viride and 


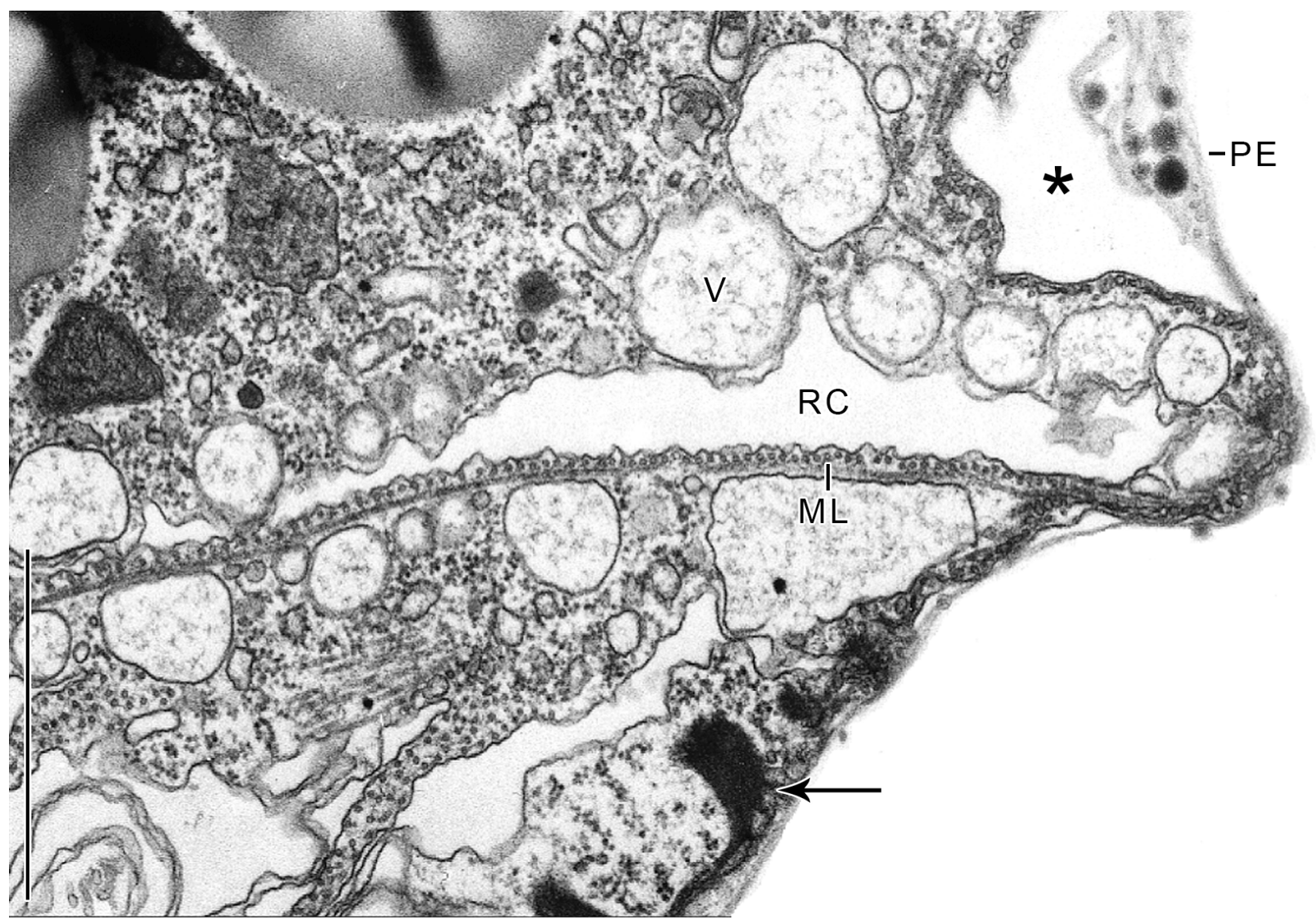

Fig. 11. Ring-canal of Limnostrombidium viride in the transmission electron microscope. The transverse section of the organelle shows its position between the anterior furrow (asterisk) and the stripe of extrusome attachment sites (arrow denotes the electron-dense cap of an empty "extrusome chamber"). Vesicles are adjacent to the irregular anterior membrane portion of the canal, while the posterior portion is underlain by two layers of perpendicularly orientated microtubules. ML, two layers of microtubules; PE, perilemma; RC, lumen of ringcanal; V, vesicles of unknown function. Scale bar: $1 \mu \mathrm{m}$.

L. pelagicum (Agatha 2004a, c; Agatha and StrüderKypke 2014). The cells investigated are identified as L. viride (Stein, 1867) Krainer, 1995 based on several characters. They differ from L. pelagicum (Kahl, 1932) Krainer, 1995 in the possession of sequestered plastids, larger cell sizes, more buccal membranelles, and more dikinetids in the ventral kinety [for a detailed species comparison see Foissner et al. (1999)]. The species had originally been described by Stein (1867) as Strombidium viride and had been transferred by Krainer (1995) to the genus Limnostrombidium.

The sequences of the small (accession no. KU525754) and large (accession no. KU525737) subunit ribosomal rDNA genes of $L$. viride were analysed by Gao et al. (2016); however, the identification of the specimen sequenced cannot be verified as the authors merely published a stamp-sized micrograph of a protargol-stained specimen that is assumed to be conspecific.
The present study is the first providing transmission electron microscopical details on $L$. viride, as the data published by Rogerson et al. (1989) on our species (reported as Strombidium viride) might actually refer to Pelagostrombidium mirabile. The authors mention the lack of a somatic ciliature and the occurrence of an argyrophilic "circumferential paratene at the equator" in silver nitrate-stained cells, and the cells possess a long buccal portion of the adoral zone. The term circumferential paratene was occasionally used for the girdle kinety plus the stripe of extrusome attachment sites [e.g., Krainer (1991), Foissner (1994)]. The term "circumferential paratene" is defined, following Lynn (2008) as "repeating kinetid patterns at right angles to the longitudinal axis of the ciliate's body..". Since the kinetids of the paratenes thus do not form a true kinety, the term should be abolished in the descriptions of oligotrichids (Agatha 2004a). 
184 C. F. Bardele et al.

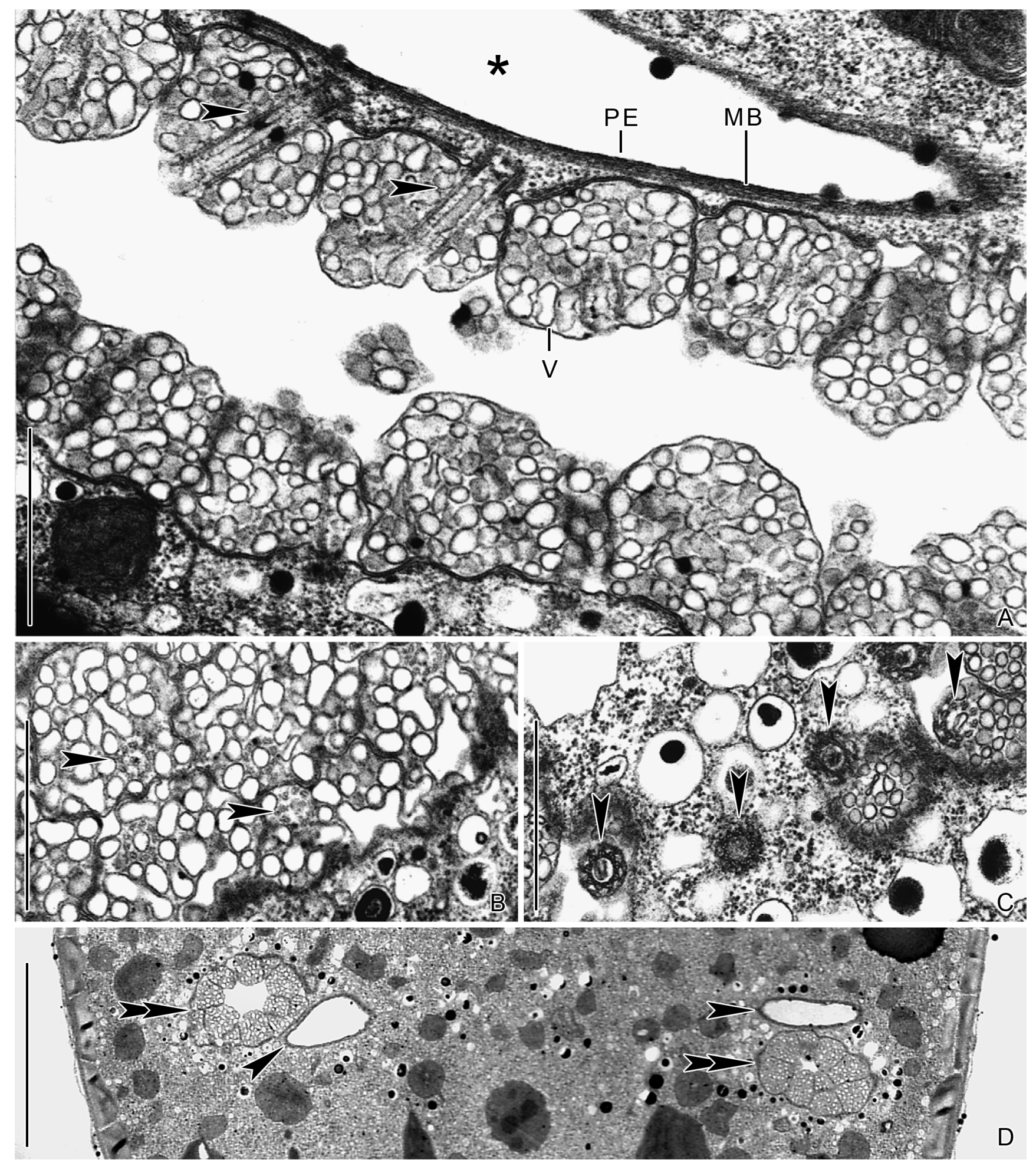

Fig. 12. Neoformation organelles in dividers of Limnostrombidium viride in the transmission electron microscope. (A) Oblique section of the organelle's distal (asterisk) and proximal portions with the outgrowing cilia of the oral primordium. The axonemes (arrowheads) are very short, lack the central pair of microtubules, and are bulbous because being embedded in many vesicles. (B) Cross section of cilia. Their axonemes already possess the " $9 \times 2+2$ " ultrastructure (arrowheads). (C) Tangential section of the neoformation organelle showing cross sections of cilia (arrowheads) and vesicles with electron-dense content of unknown function. (D) Longitudinal section of the posterior cell portion. Both the unciliated (arrowhead) and ciliated (double arrowhead) portions of the organelle are shown twice in cross section. MB, cell membrane; PE, perilemma; V, vesicles. Scale bars: $1 \mu \mathrm{m}(\mathrm{A}-\mathrm{C}), 5 \mu \mathrm{m}(\mathrm{D})$. 


\section{Oral ciliature}

In oligotrichids, choreotrichids, and the halteriid hypotrichs, the apically located adoral membranelles are not only employed in upstream filtration, but also in locomotion. The acquisition of this additional function is considered an adaptation to the planktonic life style (Lynn and Kolisko 2017). In contrast to oligotrichids and choreotrichids, a separation in "collar" and "buccal" membranelles differing in the length of their cilia and width of their polykinetids is usually not found in euplotids and hypotrichs.

Ultrastructure of membranelles. The euplotids, hypotrichs (incl. halteriids), oligotrichids, and choreotrichids differ in the number of square-packed basal body rows constituting the paramembranelles. In oligotrichids and choreotrichids, the adoral polykinetids are composed of three almost equally long rows of basal bodies, except for the two-rowed proximalmost polykinetid (Fauré-Fremiet and Ganier 1970, Laval 1972, Grim 1987, Petz and Foissner 1992, Modeo et al. 2003). The membranelles of euplotids and typical hypotrichs are four-rowed, except for three-rowed ones at the distal end of the membranellar zone and a tworowed membranelle at the proximal end (de Puytorac et al. 1976, Wirnsberger and Hausmann 1988, Wirnsberger-Aescht et al. 1989).

The links between the basal bodies are very similar in hypotrichs (Grain 1972, Grim 1972, de Puytorac et al. 1976, Bakowska and Jerka-Dziadosz 1978), the oligotrichid $L$. viride (this study), the aloricate choreotrichid Rimostrombidium (Grim 1987), and the tintinnids (Laval-Peuto and Brownlee 1986). Kinetodesmal fibrils are absent in the membranellar polykinetids of all aforementioned groups (Lynn 2008). The fibres associated with the membranelles in $L$. viride match the situation in hypotrichs [incl. Halteria; Grain (1972), Grim (1972), de Puytorac et al. (1976), Bakowska and Jerka-Dziadosz (1978), Lynn (2008)]. In the aloricate choreotrichid Rimostrombidium lacustre (reported as Strobilidium velox), the microtubules originating at the third basal body row have a different position and extend obliquely anteriorly and posteriorly; the first row has associated several radiating microtubules (Grim 1987). Tintinnids have microtubule bundles that originate in the first and third rows and connect neighbouring polykinetids (Hedin 1976, Laval-Peuto and Brownlee 1986).

Parasomal sacs occur between the basal body rows in the hypotrich and euplotid adoral polykinetids (Gliddon 1966, Grain 1972, Grim 1972, Bakowska and Jerka-Dziadosz 1978), whereas they were neither mentioned nor illustrated in the aloricate choreotrichid Rimostrombidium (Grim 1987) and tintinnids (LavalPeuto and Brownlee 1986, Laval-Peuto 1994) and were not recognisable in $L$. viride (this study).

Ultrastructure of endoral membrane. Owing to its position on the inner wall of the buccal lip, the single undulating membrane in oligotrichids had been homologised with the hypotrichs' endoral membrane (Agatha 2004c). It is most parsimonious to consider the membrane extending across the peristomial field in choreotrichids to be also an endoral membrane.

Interestingly, the endoral membrane is recognisable in scanning electron micrographs of hypotrichs, oligotrichids, and choreotrichids only when a membranous structure is partially or entirely destroyed $[L$. viride: Fig. 3A; Foissner et al. (1999), Foissner and Al-Rasheid (2006), Agatha and Tsai (2008)]. The transmission electron microscope reveals that these structures are usually composed of multiple membranous layers and are not only found in the buccal cavity of oligotrichids but also of tintinnids, hypotrichs, and euplotids (Luporini and Magagnini 1970, Nobili and Rosati Raffaelli 1971, Sokolova and Gerassimova 1984, Laval-Peuto et al. 1986, Sokolova et al. 1986, Foissner et al. 2005); the homology of these structures is uncertain.

Several protargol-stained species and some transmission electron microscopic studies reveal the endoral to be composed of a single row of basal bodies; contradicting descriptions (Krainer 1991, Modeo et al. 2003) could not be confirmed and are highly unlikely. Thin sections show that the basal bodies are identically orientated in many/all hypotrichs [incl. Halteria; Grain (1972), Grim (1972), Bakowska and Jerka-Dziadosz (1978)] and the Oligotrichea (this study, Laval-Peuto et al. 1986, Grim 1987, Modeo et al. 2003); hence, it is a stichomonad membrane in the sense of de Puytorac and Grain (1976). Yet, the organisation of stichomonad membranes is imprecisely defined and varies (Wirnsberger and Hausmann 1988).

Our findings are similar to those of Bakowska and Jerka-Dziadosz (1978) concerning the electron-dense material obliquely linking the endoral basal bodies and the microtubules extending on both sides of the endoral. The aloricate choreotrichid Rimostrombidium has the endoral basal bodies associated with nematodesmata and two short rows of microtubules on their left sides, which extend parallel to the peristomial field and the endoral cilia; the basal bodies are linked on their right sides (Grim 1987). Tintinnids have microtubular bun- 
dles extending perpendicularly on both sides of the basal bodies and deep nematodesmata (Laval-Peuto and Brownlee 1986, Laval-Peuto 1994). The endoral of L. viride deviates from the previous patterns, possessing two diverging bundles of microtubules on the basal bodies' left sides and microtubular ribbons extending obliquely anteriorly on their right sides (Fig. 3D). The microtubules originating in the endoral membrane apparently support the buccal cavity, the cytopharynx, and the lip in hypotrichs (Bakowska and Jerka-Dziadosz 1978) and L. viride (this study) and the peristomial field in Rimostrombidium (Grim 1987).

Parasomal sacs associated with the endoral are found in at least some hypotrichs (Wirnsberger and Hausmann 1988), while they were not mentioned in the aloricate choreotrichid Rimostrombidium (Grim 1987) and tintinnids (Laval-Peuto and Brownlee 1986) and were not visible in $L$. viride (this study).

The concealment of the endoral by the membranous sheet could suggest that it has lost its function. However, the moving endoral cilia underneath the membranous layers might nevertheless cause pumping movements of the peristomial field carrying food items into the buccal cavity; such movements are extremely distinct in tintinnids (SA own observ., Laval-Peuto et al. 1986).

\section{Somatic ciliature}

Dikinetids are assumed to represent the plesiomorphic character state in euplotids, hypotrichs, and Oligotrichea (Agatha 2004a, Agatha and Strüder-Kypke 2007). Following the hypothesis on the evolution of somatic ciliary patterns in Oligotrichea, only each (previously) anterior dikinetidal basal body has associated a usually 2-6 $\mu \mathrm{m}$ long and thus clearly recognisable cilium in euplotids (Ruffolo 1976), hypotrichs (Berger 1999, 2006, 2008, 2011), oligotrichids (Fauré-Fremiet and Ganier 1970, Modeo et al. 2003), and an aloricate form supposedly branching basally in the choreotrichids [Leegaardiella ovalis; Agatha (2004a), Agatha and Strüder-Kypke (2007), Agatha (2011), Agatha and Strüder-Kypke (2014)]. In the latter group, there is a somewhat greater variability in length and orientation of the somatic cilia, ranging from short and inconspicuous ones extending parallel to the cell surface in strobilidiids (Agatha et al. 2005) to long and highly mobile ones in tintinnids (Fauré-Fremiet 1924, Agatha and Tsai 2008).

The cilia of the somatic kineties in euplotids, hypotrichs, oligotrichids, and choreotrichids are normally shaped, except for the club-shaped girdle cilia in Limnostrombidium, which were previously considered to be an apomorphy for the genus (Agatha 2004c). Electrondense material which is associated with the axonemes and causes the conspicuous shape of the girdle cilia in L. viride (this study; Figs 4A, 5A, D) has also been found in other oligotrichids, namely in Strombidium sulcatum (Fauré-Fremiet and Ganier 1970) and S. inclinatum (Modeo et al. 2003); however, it is less voluminous in these species. Despite the uncertainties in the determination of the species sequenced, the topology of the most recent $18 \mathrm{~S}$ phylogeny (Santoferrara et al. 2017) suggests that the occurrence of electron-dense material in somatic cilia is not restricted to the genus Limnostrombidium or another monophyletic grouping.

Kahl (1932) hypothesised a sensory function for these cilia, which are apparently not or not considerably involved in locomotion of oligotrichids and hypotrichs. Fauré-Fremiet and Ganier (1970) actually named the electron-dense structures associated with the axonemes in Strombidium sulcatum paraflagellar bodies as in euglenoids, for which a photoreceptor function has been demonstrated (Häder and Iseki 2017). Club-shaped cilia with a potentially sensory function are found in the brush rows of a large variety of ciliates. The brush cilia vary in their axonemal structures, i.e., the structure is retained (Hiller 1993), the links between the microtubules are missing (Golińska 1982), or the central microtubules are absent (Bardele et al. 2017). Data on protists and metazoans indicate that a sensory function is not restricted to primary (sensory) cilia with " $9 \times 2+0$ "axonemes (Hubert et al. 1975, Fenchel and Finlay 1986, Ibañez-Tallon et al. 2003, Bloodgood 2010, Satir 2017). Hence, the somatic cilia of $L$. viride, especially those of the girdle kinety, might have a sensory function despite their common " $9 \times 2+2$ "-axonemes. While we could not find any clue which stimulus (light, mechanical, or chemical) is perceived by the girdle cilia in $L$. viride, at least some support for their sensory function could be provided by the discovery of highly ordered intramembranous particles as typical for sensory cilia up to mammals [Figs 5B, C; Bardele (1981), Schrenk and Bardele (1987)].

A detailed comparison with somatic cilia in choreotrichids is currently impossible owing to the scarcity of data. Neither the study on Rimostrombidium lacustre [reported as Strobilidium velox; Grim (1987)] nor the investigations on tintinnids reported electron-dense material associated with the axonemes in a way we found it (Laval 1972, Hedin 1975, Laval-Peuto 1975, 
Hedin 1976, Laval-Peuto et al. 1979, Sokolova and Gerassimova 1984, Sokolova et al. 1986), and none of the studies performed freeze-fracture analyses. Interestingly, the hypotrich ciliate Halteria grandinella is more similar to a Strombidium species than to hypotrichs and euplotids in its particle arrays in the cell membrane of somatic cilia despite their different lengths (very long vs. very short) and functions [jumping vs. perception of stimuli; Bardele (1981)]. The polarised arrangement of lasiosomes (dense arrays of granules close to the anterior portion of the axoneme) in the dorsal bristle cilia of the euplotids Euplotes and Certesia might indicate a sensory function in these ciliates (Görtz 1982), while such structures had neither been found in other euplotids (Aspidisca, Discocephalus, Euplotidium, Uronychia) and hypotrichs nor in L. viride (this study, Ruffolo 1976, Görtz 1982, Wicklow 1982, Dallai and Luporini 1983, Wicklow 1983, Rosati et al. 1987, Lenzi and Rosati 1993, Morelli et al. 1996, Lynn 2008).

Condylocilia, a kind of clavate cilia, are associated with (i) the posterior dikinetidal basal bodies in euplotids, in which they lack the central microtubules (Grimes and Adler 1976, Ruffolo 1976, Görtz 1982, Morelli et al. 1996, Lynn 2008), and (ii) the right girdle basal bodies in $L$. viride (this study). Very short and distinctly bent cilia are associated with the posterior ventral basal bodies in L. viride like in two Strombidiidae, which have similar cilia also at each right girdle basal body (Fauré-Fremiet and Ganier 1970, Modeo et al. 2003). The discocilia (paddle cilia) described by Wasik and Mikołajczyk (1991) in the tintinnid Cymatocylis convallaria are very likely artefacts, as the same phenomenon was only found in insufficiently fixed tintinnids (e.g., Agatha 2010) but never during detailed live observations.

According to the hypotheses on somatic ciliary pattern evolution in Oligotrichea, the somatic dikinetids in euplotids, hypotrichs, and oligotrichids are considered homologous, i.e., the previously anterior dikinetidal basal bodies become the left basal bodies in the curved girdle kinety (Agatha 2004a, Agatha and Strüder-Kypke 2007, Agatha 2011, Agatha and Strüder-Kypke 2012); the orientation of the ventral dikinetids has usually not changed. While some ultrastructural data are available on euplotid and hypotrich dikinetids (Lynn 2008), this is the first description of a dikinetid and its associated structures in oligotrichids.

In the dorsal dikinetids of euplotids, the anterior basal body has associated a tangential transverse ribbon and sometimes a single postciliary microtubule, while the posterior basal body has a divergent postciliary ribbon and a laterally-directed, striated kinetodesmal fibril. In hypotrichs, the ultrastructure of the dorsal dikinetids is more variable, but typically matches that of the euplotids, except for the absence of parasomal sacs and the generally transient kinetodesmal fibril (Lynn 2008).

The studied girdle dikinetids of $L$. viride differ from the dorsal dikinetids in euplotids and hypotrichs by (i) permanent kinetodesmal fibrils (vs. transient in hypotrichs), (ii) the absence of a single postciliary microtubule at the anterior basal bodies (vs. usually present in euplotids and hypotrichs), and (iii) the lack of parasomal sacs (vs. present in euplotids). Furthermore, the dikinetids have an electron-dense hook-shaped structure originating from triplets 1 and 2 of the right basal body and an electron-dense structure extending tangentially near triplets 1 and 2 of the left basal body (Figs 4B, $5 \mathrm{E}$ ); both had not been reported from the supposedly homologous dikinetids in euplotids and hypotrichs. The presence of transverse ribbons associated with the left girdle basal bodies in L. viride is uncertain and requires verification.

In tintinnids, the somatic ciliature consists of some dikinetids and many monokinetids, but merely the ultrastructure of monokinetids had been described as yet (Hedin 1976, Laval-Peuto and Brownlee 1986, LavalPeuto 1994); a detailed investigation on Schmidingerella meunieri will soon be published (Gruber et al. 2018). Interestingly, the postciliary ribbons extend parallel to the kinety axis and terminate posteriorly to the second following kinetid, overlapping the postciliary microtubules of the next kinetid; such a pattern is not found in L. viride.

In L. viride (this study), Strombidiidae (Agatha and Riedel-Lorjé 1997, Agatha 2004b), and the aloricate choreotrichid Strombidinopsis minima (Agatha 2003b), the dikinetids are anticlockwise inclined to the kinety axis (surface view), while clockwise inclined in euplotids (Ruffolo 1976, Wicklow 1983, Morelli et al. 1996) and hypotrichs (Grimes and Adler 1976, Wirnsberger-Aescht et al. 1989). The dikinetidal basal bodies extend parallel to each other in euplotids (Ruffolo 1976, Wicklow 1983, Lenzi and Rosati 1993) and hypotrichs (Grimes and Adler 1976), while the posterior ventral and left girdle basal bodies of oligotrichid dikinetids are obliquely orientated (this study, Fauré-Fremiet and Ganier 1970, Modeo et al. 2003); data for choreotrichids are not available, but will soon be published for a tintinnid (Gruber et al. 2018). 


\section{Cortex}

Although its nature and function are unknown, the perilemma had been used for defining the Perilemmaphora, which unite the hypotrichs, oligotrichids, and choreotrichids (Berger 2008); accordingly, its occurrence in $L$. viride (this study) was not surprising. Likewise, electron-dense particles on and underneath the perilemma had already been reported from some oligotrichids (Rogerson et al. 1989, Modeo et al. 2003), but seem to be absent in choreotrichids.

In oligotrichids, the cell membrane is underlain by small alveoli and a layer of densely spaced, longitudinally orientated microtubules followed by a layer of polygonal polysaccharidic platelets constituting the hemitheca in the cell portion posteriorly to the girdle kinety (this study, Fauré-Fremiet and Ganier 1970, Modeo et al. 2003). The hemitheca is considered a synapomorphy of the oligotrichids (Agatha et al. 2005), while layers of longitudinally orientated microtubules as in L. viride (this study) are known from the hypotrich cortex and the ventral side of euplotids (see survey by Fleury 1988).

\section{Nuclei}

The macronuclei of spirotrichs, except for licnophorids, are characterised by the occurrence of replication bands in dividers (Lynn 2008). The present study is one of the very few ultrastructural investigations on macronuclei in oligotrichids and choreotrichids (Laval 1972, Salvano 1974, Hedin 1975, Salvano 1975, Sokolova and Gerassimova 1984, Laval-Peuto and Febvre 1986). The most detailed study on the replication band is from Salvano $(1974,1975)$ on Strombidium sulcatum and matches perfectly the observations in L. viride, except for a separation of the bright zone (site of beginning biosynthesis) from the zone of DNA replication with its fine structure.

\section{Extrusomes}

In former times, the proteinaceous trichites of oligotrichids were occasionally considered skeletal elements (Fauré-Fremiet 1924, Fauré-Fremiet and Ganier 1970) or contractile fibres (Lohmann 1908), but Kahl (1932) noticed an ejection of these organelles like in other extrusomes. These observations are supported by Penard (1920), Montagnes et al. (1988), Modeo et al. (2001), Rosati and Modeo (2003), Agatha (2003a), Agatha et al. (2005), and the present study (Figs 9A, D). In $L$. viride (this study), triggering extrusion was difficult and the elongation of ejected extrusomes found in other oligotrichids could not be observed possibly because they were fixed during extrusion. Attachment rosettes with an " $8+1$ "-pattern of intramembranous particles at the tips of the trichites, as typical for most extrusive organelles in ciliates (except for Suctoria with a "12+1"-pattern; Bardele, unpubl. observ.), were seen in freeze-fracture micrographs (Fig. 10A). As yet, it is unknown whether the extrusomes are used for food capture or for defence against certain predators.

The arrangement of trichites in clusters or rows and their associated fibrillar structures are considered a promising character complex for future cladistic analyses, disentangling the non-monophylies emerging in genetic phylogenies (Agatha 2004c).

The ultrastructure of the extrusome girdle had been described in three oligotrichids, i.e., the strombidiids Strombidium sulcatum, S. inclinatum, and Novistrombidium testaceum, and illustrated in the tontoniid $\mathrm{La}$ boea strobila (Fauré-Fremiet and Ganier 1970, Modeo et al. 2001, Agatha et al. 2004). The extrusomes in these species match rather well those in $L$. viride, except for the hexagonal lumen, which seems to be restricted to immature organelles, while the mature trichites have an electron-dense "core". Likewise, the electron-dense rings projecting into the lumen at certain distances in the other oligotrichids could only be found in the immature organelles of $L$. viride (cp. Figs 9C, D with Figs $10 \mathrm{~B}, \mathrm{C})$. The extrusomes misinterpreted as nematodesmata by Rogerson et al. (1989) in Pelagostrombidium mirabile (reported as $L$. viride) possess like $L$. viride an electron-dense "core". In contrast to our specimens and Laboea strobila, the individual extrusomes of Strombidium inclinatum, S. sulcatum, and Novistrombidium testaceum are not enclosed by a membrane.

While the formation of two-rowed units is recognisable in scanning electron micrographs of the monotypic genus Laboea, TEM sections do not show such a (distinct) separation of the units as in L. viride. Further, the grouping of these units into larger clusters seems to represent a new feature demonstrated by $L$. viride. Electron-dense material underlays the cortex in L. viride, Strombidium inclinatum, and S. sulcatum and forms a cap for each extrusome (this study, Fauré-Fremiet and Ganier 1970, Modeo et al. 2001).

To our knowledge, there are no detailed studies of the development of the oligotrichid extrusomes. Rosati and Modeo (2003) suggested an involvement of the endoplasmic reticulum or the Golgi complex. Here, we present preliminary observations, which fit structures recognisable in the tontoniid Laboea strobila [Fig. $4 \mathrm{i}$ in Agatha et al. (2004)]. 


\section{Ring-canal}

The maintenance of a hyperosmotic internal state is characteristic of freshwater and brackish water ciliates and is performed by one or several contractile vacuoles. It is assumed that the Oligotrichea evolved in the sea and entered freshwater at least eight times independently. A typical contractile vacuole has been reported from freshwater strombidiids, aloricate choreotrichids, tintinnids, as well as from a brackish water aloricate choreotrichid (Foissner and Wilbert 1979, Foissner et al. 1988, Petz and Foissner 1992, Krainer 1995, Agatha and Riedel-Lorjé 1998, Foissner et al. 1999, Küppers et al. 2006, Potapskaya and Obolkina 2012).

While Roux (1899) observed also a typical contractile vacuole in $L$. viride, other live observations described a unique, potentially osmoregulatory organelle, which had neither been observed in its congener L. pelagicum nor in Pelagostrombidium species (Penard 1920, Kahl 1932). The latter species apparently also lack common contractile vacuoles. Here, the first transmission electron microscopic data on the ring-canal are presented, but its functionality remains obscure. The different position of the organelle in our specimens and those described by Penard (1920), namely anterior vs. posterior to the extrusome attachment sites is attributed to the difficult live observations.

\section{Neoformation organelle and cell division}

The neoformation organelle is one of the most fascinating organelles of the Pelagostrombidiidae. It was assumed quite early by Penard (1920) that this subsurface tube is the place of hypoapokinetal stomatogenesis, which was supported by data from live and silver-stained specimens (Kormos and Kormos 1958, Krainer 1991, Foissner 1996). For the first time, the formation of the new oral cilia within the proximal portion of the tube has here been documented by transmission electron micrographs. The constitution of the wall in the unciliated tube portion fits that of the cortex. In the proximal tube portion, the numerous small vesicles around the growing axonemes are interpreted as stocks of membrane material allocated for the further outgrowth of the membranellar cilia. The countless mitochondria accompanying the neoformation organelle provide the energy necessary for stomatogenesis, i.e., the formation of the oral ciliature including the complex assembly of the three-rowed adoral membranelles.

\section{Nomenclatural acts}

Data gathered during the past years, including those of the present study and particularly the conclusive exclusion of the halteriids from the Oligotrichea and their affiliation with the hypotrichs by Lynn and Kolisko (2017), necessitate the improvement of several diagnoses.

\section{Class Oligotrichea Bütschli, 1887}

Improved diagnosis. Cell usually globular to obconical. Macronucleus with replication band. Adoral zone of membranelles conspicuous, occupies apical cell portion. Adoral membranelles three-rowed, except for two-rowed proximalmost ones. Somatic kinetids as monokinetids, dikinetids with two cilia, dikinetids with cilia at the (initially) anterior or posterior basal body. Reorganisation of ciliature indistinct or absent. Endoral membrane stichomonad, originates probably de novo, might secondarily be lost (Cyrtostrombidiidae); paroral membrane secondarily absent. Stomatogenesis hypoapokinetal, cell division enantiotropic. Mainly marine plankton.

\section{Order Oligotrichida Bütschli, 1887}

Improved diagnosis. Adoral zone of membranelles $\mathrm{C}$-shaped with distinct ventral gap. Endoral membrane extends on inner wall of buccal lip, might secondarily be lost (Cyrtostrombidiidae). Peristome usually spoon-shaped to funnel-shaped, parallel to main cell axis. Mostly with acicular or rod-shaped extrusomes of trichite-type. Usually polysaccharidic cortical platelets in posterior cell portion. Somatic ciliature generally comprises two kineties, a curved girdle kinety and a usually longitudinal ventral kinety. Somatic kineties composed of dikinetids, each has associated a clearly recognisable cilium only with the (initially) anterior basal body; kinetodesmal fibril and postciliary microtubular ribbon at the (initially) posterior basal body; presence of transverse microtubular ribbon uncertain. Often mixotrophic owing to presence of sequestered plastids. Stomatogenesis in subsurface tube. Mainly marine plankton.

\section{Family Pelagostrombidiidae Agatha, 2004}

Improved diagnosis. Oligotrichida with collar and buccal membranelles and endoral membrane. Somatic cilia and ventral kinety might secondarily be absent (Pelagostrombidium). Nuclear apparatus comprises one macronucleus and one micronucleus. Stomatogenesis in neoformation organelle. Freshwater. 


\section{Genus Limnostrombidium Krainer, 1995}

Improved diagnosis. Pelagostrombidiidae with girdle kinety and ventral kinety. Apical protrusion spoonshaped. Clavate cilia and condylocilia in girdle kinety, normally shaped and stubby cilia in ventral kinety. Neoformation organelle tube-shaped. Buccal zone portion continuous with collar portion, extends obliquely, terminating anteriorly to level of girdle kinety. Ringcanal with supposed osmoregulatory function might be present.

Acknowledgements. CFB and NS prepared the material, made the micrographs, and wrote a preliminary version of the manuscript. The final up-to-date version of the manuscript has been written by SA, who especially contributed to the discussion and added the diagnoses. The work of SA was financially supported by the Austrian Science Fund FWF Project 28790. Thanks go to Sigrid Schultheiß for excellent technical support.

\section{REFERENCES}

Agatha S. (2003a) Morphology and ontogenesis of Novistrombidium apsheronicum nov. comb. and Strombidium arenicola (Protozoa, Ciliophora): a comparative light microscopical and SEM study. Eur. J. Protistol. 39: 245-266

Agatha S. (2003b) Redescription of Strombidinopsis minima (Gruber, 1884) Lynn et al., 1991 (Protozoa, Ciliophora), with notes on its ontogenesis and distribution. Eur. J. Protistol. 39: 233244

Agatha S. (2004a) Evolution of ciliary patterns in the Oligotrichida (Ciliophora, Spirotricha) and its taxonomic implications. Zoology 107: 153-168

Agatha S. (2004b) New observations on the tontoniid ciliate Spirotontonia grandis (Suzuki and Han, 2000) Agatha, 2004 (Ciliophora, Oligotrichida, Tontoniidae); comparison with the similar Laboea strobila. Eur. J. Protistol. 40: 295-301

Agatha S. (2004c) A cladistic approach for the classification of oligotrichid ciliates (Ciliophora: Spirotricha). Acta Protozool. 43: 201-217

Agatha S. (2010) A light and scanning electron microscopic study of the closing apparatus in tintinnid ciliates (Ciliophora, Spirotricha, Tintinnina): a forgotten synapomorphy. J. Eukaryot. Microbiol. 57: 297-307

Agatha S. (2011) Updated hypothesis on the evolution of oligotrichid ciliates (Ciliophora, Spirotricha, Oligotrichida) based on somatic ciliary patterns and ontogenetic data. Eur. J. Protistol. 47: 51-56

Agatha S., Riedel-Lorjé J. C. (1997) Morphology, infraciliature, and ecology of halteriids and strombidiids (Ciliophora, Oligotrichea) from coastal brackish water basins. Arch. Protistenk. 148: $445-459$

Agatha S., Riedel-Lorjé J. C. (1998) Morphology, infraciliature, and ecology of some strobilidiine ciliates (Ciliophora, Oligotrichea) from coastal brackish water basins of Germany. Eur. J. Protistol. 34: 10-17

Agatha S., Riedel-Lorjé J. C. (2006) Redescription of Tintinnopsis cylindrica Daday, 1887 (Ciliophora: Spirotricha) and unification of tintinnid terminology. Acta Protozool. 45: 137-151
Agatha S., Strüder-Kypke M. C. (2007) Phylogeny of the order Choreotrichida (Ciliophora, Spirotricha, Oligotrichea) as inferred from morphology, ultrastructure, ontogenesis, and $\mathrm{SSr}-$ RNA gene sequences. Eur. J. Protistol. 43: 37-63

Agatha S., Strüder-Kypke M. C. (2012) Reconciling cladistic and genetic analyses in choreotrichid ciliates (Ciliophora, Spirotricha, Oligotrichea). J. Eukaryot. Microbiol. 59: 325-350

Agatha S., Strüder-Kypke M. C. (2014) What morphology and molecules tell us about the evolution of Oligotrichea (Alveolata, Ciliophora). Acta Protozool. 53: 77-90

Agatha S., Tsai S.-F. (2008) Redescription of the tintinnid Stenosemella pacifica Kofoid and Campbell, 1929 (Ciliophora, Spirotricha) based on live observation, protargol impregnation, and scanning electron microscopy. J. Eukaryot. Microbiol. 55: $75-85$

Agatha S., Strüder-Kypke M. C., Beran A. (2004) Morphologic and genetic variability in the marine planktonic ciliate Laboea strobila Lohmann, 1908 (Ciliophora, Oligotrichia), with notes on its ontogenesis. J. Eukaryot. Microbiol. 51: 267-281

Agatha S., Strüder-Kypke M. C., Beran A., Lynn D. H. (2005) Pelagostrobilidium neptuni (Montagnes and Taylor, 1994) and Strombidium biarmatum nov. spec. (Ciliophora, Oligotrichea): phylogenetic position inferred from morphology, ontogenesis, and gene sequence data. Eur. J. Protistol. 41: 65-83

Bakowska J., Jerka-Dziadosz M. (1978) Ultrastructural analysis of the infraciliature of the oral apparatus in Paraurostyla weissei (Hypotricha). Acta Protozool. 17: 285-301 + Plates I-V

Bardele C. F. (1981) Functional and phylogenetic aspects of the ciliary membrane: a comparative freeze-fracture study. BioSystems 14: $403-421$

Bardele C. F. (1983) Mapping of highly ordered membrane domains in the plasma membrane of the ciliate Cyclidium glaucoma. J. Cell Sci. 61: 1-30

Bardele C. F., Schultheiß S., Lynn D. H., Wright A.-D. G., Dominguez-Bello M. G., Obispo N. E. (2017) Aviisotricha hoazini $\mathrm{n}$. gen., n. sp., the morphology and molecular phylogeny of an anaerobic ciliate from the crop of the Hoatzin (Opisthocomus hoazin), the cow among the birds. Protist 168: 335-351

Berger H. (1999) Monograph of the Oxytrichidae (Ciliophora, Hypotrichia). Monographiae Biologicae 78. Kluwer Acad. Publishers, Dordrecht, Netherlands

Berger H. (2006) Monograph of the Urostyloidea (Ciliophora, Hypotricha). Monographiae Biologicae 85. Springer, Dordrecht, Netherlands

Berger H. (2008) Monograph of the Amphisiellidae and Trachelostylidae (Ciliophora, Hypotricha). Monographiae Biologicae 88. Springer, Dordrecht, Netherlands

Berger H. (2011) Monograph of the Gonostomatidae and Kahliellidae (Ciliophora, Hypotricha). Monographiae Biologicae 90. Springer, Dordrecht, Heidelberg, London, New York

Bloodgood R. A. (2010) Sensory reception is an attribute of both primary cilia and motile cilia. J. Cell Sci. 123: 505-509

Dallai R., Luporini P. (1983) Patterned arrays of intramembranous particles in the bristle cilia of three different species of Euplotes. J. Protozool. 30: 426-431

Fauré-Fremiet E. (1924) Contribution à la connaissance des infusoires planktoniques. Bull. biol. Fr. Belg. Suppl. 6: 1-171

Fauré-Fremiet E., Ganier M.-C. (1970) Structure fine du Strombidium sulcatum $\mathrm{Cl}$. et L. (Ciliata Oligotrichida). Protistologica 6: 207-223

Fenchel T., Finlay B. J. (1986) The structure and function of Müller vesicles in loxodid ciliates. J. Protozool. 33: 69-76 
Fleury A. (1988) The use of correlated ultrastructural and morphogenetic characters in evolutionary taxonomy of hypotrich ciliates. BioSystems 21: 309-316

Foissner W. (1994) Progress in taxonomy of planktonic freshwater ciliates. Mar. Microb. Food Webs 8: 9-35

Foissner W. (1996) Ontogenesis in ciliated protozoa, with emphasis on stomatogenesis. In: Ciliates: Cells as Organisms, (Eds. K. Hausmann, P. C. Bradbury). G. Fischer Verlag, Stuttgart, 95-177

Foissner W., Al-Rasheid K. (2006) A unified organization of the stichotrichine oral apparatus, including a description of the buccal seal (Ciliophora: Spirotrichea). Acta Protozool. 45: 1-16

Foissner W., Wilbert N. (1979) Morphologie, Infraciliatur und Ökologie der limnischen Tintinnina: Tintinnidium fluviatile Stein, Tintinnidium pusillum Entz, Tintinnopsis cylindrata Daday und Codonella cratera (Leidy) (Ciliophora, Polyhymenophora). J. Protozool. 26: 90-103

Foissner W., Skogstad A., Pratt J. R. (1988) Morphology and infraciliature of Trochiliopsis australis n. sp., Pelagohalteria viridis (Fromentel, 1876) n. g., n. comb., and Strobilidium lacustris n. sp. (Protozoa, Ciliophora). J. Protozool. 35: 489-497

Foissner W., Blatterer H., Berger H., Kohmann F. (1991) Taxonomische und ökologische Revision der Ciliaten des Saprobiensystems. Band I: Cyrtophorida, Oligotrichida, Hypotrichia, Colpodea. Informationsberichte des Bayer. Landesamtes für Wasserwirtschaft 1/91. Informationsberichte des Bayer. Landesamtes für Wasserwirtschaft, Munich

Foissner W., Berger H., Blatterer H., Kohmann F. (1995) Taxonomische und ökologische Revision der Ciliaten des Saprobiensystems. Band IV: Gymnostomatea, Loxodes, Suctoria. Informationsberichte des Bayer. Landesamtes für Wasserwirtschaft 1/95. Informationsberichte des Bayer. Landesamtes für Wasserwirtschaft, Munich

Foissner W., Berger H., Schaumburg J. (1999) Identification and Ecology of Limnetic Plankton Ciliates. Informationsberichte des Bayer. Landesamtes für Wasserwirtschaft 3/99. Bayer. Landesamt für Wasserwirtschaft, Munich

Foissner W., Müller H., Weisse T. (2005) The unusual, lepidosomecoated resting cyst of Meseres corlissi (Ciliophora: Oligotrichea): Light and scanning electron microscopy, cytochemistry. Acta Protozool. 44: 201-215

Gao F., Li J., Song W., Xu D., Warren A., Yi Z., Gao S. (2016) Multi-gene-based phylogenetic analysis of oligotrich ciliates with emphasis on two dominant groups: cyrtostrombidiids and strombidiids (Protozoa, Ciliophora). Mol. Phylogenet. Evol. 105: $241-250$

Gliddon R. (1966) Ciliary organelles and associated fibre systems in Euplotes eurystomus (Ciliata, Hypotrichida). I. Fine structure. J. Cell Sci. 1: 439-448 + Figures V-XV

Golińska K. (1982) Regulation of ciliary pattern in Dileptus (Ci1iata). I. Sensory cilia and their conversion into locomotor cilia. J. Embryol. Exp. Morphol. 68: 99-114

Görtz H.-D. (1982) The behavior and fine structure of the dorsal bristles of Euplotes minuta, E. aediculatus, and Stylonychia mytilus (Ciliata, Hypotrichida). J. Protozool. 29: 353-359

Grain J. (1969) Le cinétosome et ses dérivés chez les ciliés. Ann. Biol. 8: 53-97

Grain J. (1972) Etude ultrastructurale d'Halteria grandinella O.F.M., (Cilié Oligotriche) et considérations phylogénétiques. Protistologica 8: 179-197

Greuet C., Gayol P., Salvano P., Laval-Peuto M. (1986) Preliminary report on the ultrastructural organization of the contractile ap- pendix of Tontonia appendiculariformis (Ciliophora Oligotrichina). Cell Motil. Cytoskeleton 6: 217-224

Grim J. N. (1972) Fine structure of the surface and infraciliature of Gastrostyla steinii. J. Protozool. 19: 113-126

Grim J. N. (1987) The kinetid structures of the choreotrichous ciliate Strobilidium velox and an assessment of its evolutionary lineage. J. Protozool. 34: 117-123

Grimes G. W., Adler J. A. (1976) The structure and development of the dorsal bristle complex of Oxytricha fallax and Stylonychia pustulata. J. Protozool. 23: 135-143

Gruber M. S., Mühlthaler A., Agatha S. (2018) Ultrastructural studies on a model tintinnid - Schmidingerella meunieri (Kofoid and Campbell, 1929) Agatha and Strüder-Kypke, 2012 (Ciliophora). I. Somatic kinetids with unique ultrastructure. Acta Protozool. 57: 195-214

Häder D.-P., Iseki M. (2017) Photomovement in Euglena. In: Euglena: Biochemistry, Cell and Molecular Biology, (Eds. S. Schwartzbach, S. Shigeoka). Springer, Cham: 979

Hedin H. (1975) On the ultrastructure of Favella ehrenbergii (Claparède \& Lachmann) and Parafavella gigantea (Brandt), Protozoa, Ciliata, Tintinnida. Zoon 3: 11-18

Hedin H. (1976) Microtubules and microfilaments in the tintinnid ciliate Ptychocylis minor Jörgensen. Zoon 4: 3-10

Hiller S. A. (1993) Ultrastructure of Prorodon (Ciliophora, Prostomatida). II. Oral cortex and phylogenetic conclusions. J. Eukaryot. Microbiol. 40: 486-501

Hubert G., Rieder N., Schmitt G., Send W. (1975) Bariumanreicherung in den Müllerschen Körperchen der Loxodidae (Ciliata, Holotricha) - Accumulation of Barium in Müller's Bodies of the Loxodidae (Ciliata, Holotricha). Z. Naturforsch. 30c: $422-422 a$

Ibañez-Tallon I., Heintz N., Omran H. (2003) To beat or not to beat: roles of cilia in development and disease. Hum. Mol. Genet. 12: R27-R35

Kahl A. (1932) Urtiere oder Protozoa. I: Wimpertiere oder Ciliata (Infusoria). Eine Bearbeitung der freilebenden und ectocommensalen Infusorien der Erde, unter Ausschluß der marinen Tintinnidae. 3. Spirotricha. Die Tierwelt Deutschlands und der angrenzenden Meeresteile nach ihren Merkmalen und nach ihrer Lebensweise 25. G. Fischer, Jena

Kormos J., Kormos K. (1958) Die Zellteilungstypen der Protozoen. Acta biol. hung. 8: 127-148

Krainer K.-H. (1991) Contributions to the morphology, infraciliature and ecology of the planktonic ciliates Strombidium pelagicum n.sp., Pelagostrombidium mirabile (Penard, 1916) n.g., n.comb., and Pelagostrombidium fallax (Zacharias, 1896) n.g., n. comb. (Ciliophora, Oligotrichida). Eur. J. Protistol. 27: 60-70

Krainer K.-H. (1995) Taxonomische Untersuchungen an neuen und wenig bekannten planktischen Ciliaten (Protozoa: Ciliophora) aus Baggerseen in Österreich. Lauterbornia 21: 39-68

Küppers G. C., Lopretto E. C., Claps M. C. (2006) Pelagostrobilidium wilberti n. sp. (Oligotrichea, Choreotrichida): morphology and morphogenesis. J. Eukaryot. Microbiol. 53: 477-484

Laval M. (1972) Ultrastructure de Petalotricha ampulla (Fol). Comparaison avec d'autres tintinnides et avec les autres ordres de ciliés. Protistologica 8: 369-386

Laval-Peuto M. (1975) Cortex, périlemme et réticulum vésiculeux de Cyttarocylis brandti (Cilié Tintinnide). Les ciliés à périlemme. Protistologica 11: 83-98

Laval-Peuto M. (1994) Classe des Oligotrichea Bütschli, 1887. Ordre des Tintinnida Kofoid et Campbell, 1929. In: Traité de Zo- 
ologie. Anatomie, systématique, biologie. 2. Infusoires ciliés. 2. Systématique, (Eds. P. de Puytorac). Masson, Paris, Milano, Barcelona, 181-219

Laval-Peuto M., Brownlee D. C. (1986) Identification and systematics of the Tintinnina (Ciliophora): evaluation and suggestions for improvement. Ann. Inst. océanogr., Paris 62: 69-84

Laval-Peuto M., Febvre M. (1986) On plastid symbiosis in Tontonia appendiculariformis (Ciliophora, Oligotrichina). BioSystems 19: $137-158$

Laval-Peuto M., Gold K., Storm E. R. (1979) The ultrastructure of Tintinnopsis parva. Trans. Am. microsc. Soc. 98: 204-212

Laval-Peuto M., Salvano P., Gayol P., Greuet C. (1986) Mixotrophy in marine planktonic ciliates: ultrastructural study of Tontonia appendiculariformis (Ciliophora, Oligotrichina). Mar. Microb. Food Webs 1: 81-104

Lenzi P., Rosati G. (1993) Ultrastructural study of Euplotidium itoi (Ciliata Hypotrichida). Eur. J. Protistol. 29: 453-461

Lohmann H. (1908) Untersuchungen zur Feststellung des vollständigen Gehaltes des Meeres an Plankton. Wiss. Meeresunters., Abt. Kiel 10: 128-370 + Plates IX-XVII + Tables A, B

Luporini P., Magagnini G. (1970) Recherches sur la structure fine et la biologie reproductive du cilié hypotriche Swedmarkia arenicola Dragesco. Protistologica 6: 113-125

Lynn D. H. (1988) Cytoterminology of cortical components of ciliates: somatic and oral kinetids. BioSystems 21: 299-307

Lynn D. H. (2008) The Ciliated Protozoa. Characterization, Classification, and Guide to the Literature. Springer

Lynn D. H., Kolisko M. (2017) Molecules illuminate morphology: phylogenomics confirms convergent evolution among 'oligotrichous' ciliates. Int. J. Syst. Evol. Microbiol. 67: 3676-3682

Modeo L., Petroni G., Bonaldi M., Rosati G. (2001) Trichites of Strombidium (Ciliophora, Oligotrichida) are extrusomes. J. Eukaryot. Microbiol. 48: 95-101

Modeo L., Petroni G., Rosati G., Montagnes D. J. S. (2003) A multidisciplinary approach to describe protists: redescriptions of Novistrombidium testaceum Anigstein 1914 and Strombidium inclinatum Montagnes, Taylor, and Lynn 1990 (Ciliophora, Oligotrichia). J. Eukaryot. Microbiol. 50: 175-189

Montagnes D. J. S., Lynn D. H., Stoecker D. K., Small E. B. (1988) Taxonomic descriptions of one new species and redescription of four species in the family Strombidiidae (Ciliophora, Oligotrichida). J. Protozool. 35: 189-197

Morelli A., Giambelluca A., Lenzi P., Rosati G., Verni F. (1996) Ultrastructural features of the peculiar filter-feeding hypotrich ciliate Uronychia transfuga. Micron 27: 399-406

Müller H., Wünsch C. (1999) Seasonal dynamics of cyst formation of pelagic strombidiid ciliates in a deep prealpine lake. Aquat. Microb. Ecol. 17: 37-47

Nobili R., Rosati Raffaelli G. (1971) The fine structure of the oral apparatus of some ciliate hypotrichs. Monitore zool. ital. (N.S.) 5: $65-80$

Párducz B. (1967) Ciliary movement and coordination in ciliates. Int. Rev. Cytol. 21: 91-128

Penard E. (1920) Observations sur le Strombidium viride Stein. Rev. Suisse Zool. 28: 1-9

Petz W., Foissner W. (1992) Morphology and morphogenesis of Strobilidium caudatum (Fromentel), Meseres corlissi n. sp., Halteria grandinella (Müller), and Strombidium rehwaldi n. sp., and a proposed phylogenetic system for oligotrich ciliates (Protozoa, Ciliophora). J. Protozool. 39: 159-176
Potapskaya N. V., Obolkina L. A. (2012) Two new species, Rimostrombidium vicinum and Rimostrombidium inopinatum (Oligotrichia, Ciliophora), from Lake Baikal. Zool. Zh. 91: 901-906

Pringsheim E. G. (1946) Pure cultures of Algae. Their Preparation and Maintenance. Cambridge Univ. Press, New York, London

Puytorac P. de, Grain J. (1976) Ultrastructure du cortex buccal et évolution chez les ciliés. Protistologica 12: 49-67

Puytorac P. de, Grain J., Rodrigues de Santa Rosa M. (1976) A propos de l'ultrastructure corticale du cilié hypotriche Stylonychia mytilus Ehrbg., 1838: les caractéristiques du cortex buccal adoral et paroral des Polyhymenophora Jankowski, 1967. Trans. Am. microsc. Soc. 95: 327-345

Rogerson A., Finlay B. J., Berninger U.-G. (1989) Sequestered chloroplasts in the freshwater ciliate Strombidium viride (Ciliophora: Oligotrichida). Trans. Am. microsc. Soc. 108: 117-126

Rosati G., Modeo L. (2003) Extrusomes in ciliates: diversification, distribution, and phylogenetic implications. J. Eukaryot. Microbiol. 50: 383-402

Rosati G., Verni F., Bracchi P., Dini F. (1987) An ultrastructural analysis of the ciliated protozoon Aspidisca sp. Trans. Am. microsc. Soc. 106: $31-52$

Roux J. (1899) Observations sur quelques infusoires ciliés des environs de Genéve avec la description de nouvelles espèces. Rev. Suisse Zool. 6: 557-636 + Plates XIII, XIV

Ruffolo J. J., Jr. (1976) Fine structure of the dorsal bristle complex and pellicle of Euplotes. J. Morph. 148: 469-487

Salvano P. (1974) Analyse microspectrographique dans l'ultraviolet du macronoyau de Strombidium sulcatum Clap. et L., 1859 (Cilié Hypotriche), pendant l'intercinèse. C. r. hebd. Séanc. Acad. Sci., Paris, Série D 278: 2445-2247

Salvano P. (1975) Comparaison du fonctionnement des bandes de réorganisation d'Euplotes crassus (Dujardin) et de Strombidium sulcatum Claparède et Linné après analyse microspectrographique en UV. J. Protozool. 22: 230-232

Santoferrara L. F., Alder V. V., McManus G. B. (2017) Phylogeny, classification and diversity of Choreotrichia and Oligotrichia (Ciliophora, Spirotrichea). Mol. Phylogenet. Evol. 112: 12-22

Satir P. (2017) Cilia: before and after. Cilia 6: 1

Schrenk H.-G., Bardele C. F. (1987) The fine structure of the paralabial organelle in the rumen ciliate Ophryoscolex purkinjei Stein, 1858. J. Protozool. 34: 97-104

Sokolova Y. Y., Gerassimova Z. P. (1984) The ultrastructure of the ciliates Parafavella denticulata Ehrenberg, 1840. Tsitologiya 26: $1237-1245+$ Plates I-IV

Sokolova Y. Y., Seravin L. N., Gerassimova Z. P. (1986) Membrane structures and their supposed involvement in the digestive events with the ciliate Parafavella denticulata Ehrenberg, 1890 (Tintinnina). Tsitologiya 28: 220-224

Stein F. (1867) Der Organismus der Infusionsthiere nach eigenen Forschungen in systematischer Reihenfolge bearbeitet. II. Abtheilung. 1) Darstellung der neuesten Forschungsergebnisse über Bau, Fortpflanzung und Entwickelung der Infusionsthiere. 2) Naturgeschichte der heterotrichen Infusorien. W. Engelmann, Leipzig

Stoecker D. K., Silver M. W. (1990) Replacement and aging of chloroplasts in Strombidium capitatum (Ciliophora: Oligotrichida). Mar. Biol. 107: 491-502

Stoecker D. K., Silver M. W., Michaels A. E., Davis L. H. (1989) Enslavement of algal chloroplasts by four Strombidium spp. (Ciliophora, Oligotrichida). Mar. Microb. Food Webs 3 (year 1988/1989): 79-100 
Strüder-Kypke M. C., Lynn D. H. (2003) Sequence analyses of the small subunit rRNA gene confirm the paraphyly of oligotrich ciliates sensu lato and support the monophyly of the subclasses Oligotrichia and Choreotrichia (Ciliophora, Spirotrichea). J. Zool., Lond. 260: 87-97

Trump B. F., Smuckler E. A., Benditt E. P. (1961) A method for staining epoxy sections for light microscopy. J. Ultrastruct. Res. 5: 343-348

Wasik A., Mikołajczyk E. (1991) Discocilia (paddle cilia) in the marine ciliate Cymatocylis convallaria (Tintinnina). Cell Biol. Int. Rep. 15: 485-491

Wicklow B. J. (1982) The Discocephalina (n. subord.): ultrastructure, morphogenesis and evolutionary implications of a group of endemic marine interstitial hypotrichs (Ciliophora, Protozoa). Protistologica 18: 299-330
Wicklow B. J. (1983) Ultrastructure and cortical morphogenesis in the euplotine hypotrich Certesia quadrinucleata Fabre-Domergue, 1885 (Ciliophora, Protozoa). J. Protozool. 30: 256-266

Wirnsberger E., Hausmann K. (1988) Fine structure of Pseudokeronopsis carnea (Ciliophora, Hypotrichida). J. Protozool. 35: 182-189

Wirnsberger-Aescht E., Foissner W., Foissner I. (1989) Morphogenesis and ultrastructure of the soil ciliate Engelmanniella mobilis (Ciliophora, Hypotrichida). Eur. J. Protistol. 24: 354-368

Received on $27^{\text {th }}$ September, 2018; revised on $15^{\text {th }}$ January, 2019, accepted on $22^{\text {nd }}$ January, 2019 